UC-NRLF

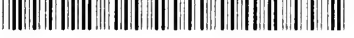

B $3755 \quad 638$ 


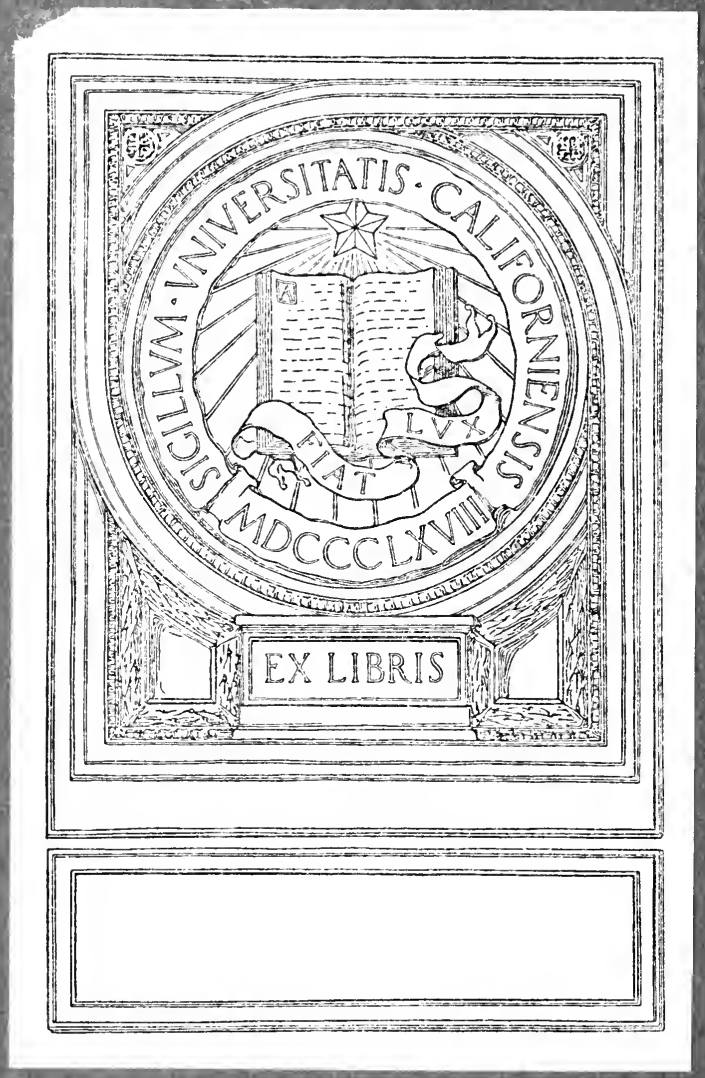





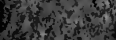

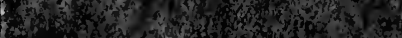

S.

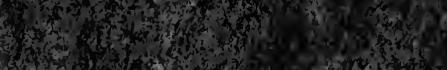

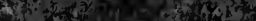

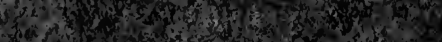

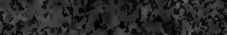

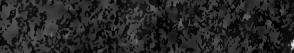

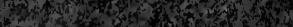

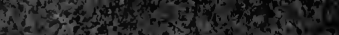

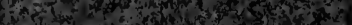

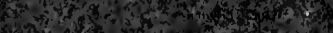

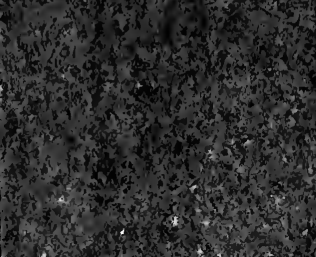

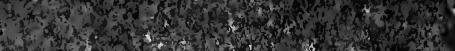

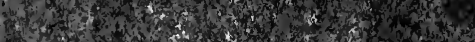

3. 3 r.

20.

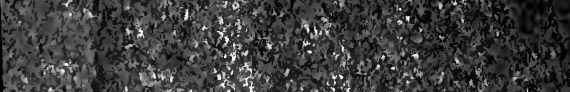

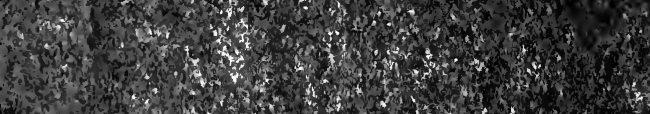

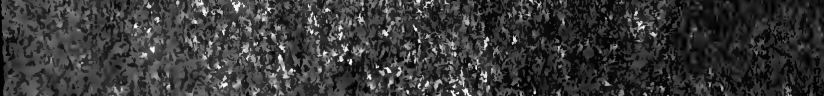

1.

3 (1) F.

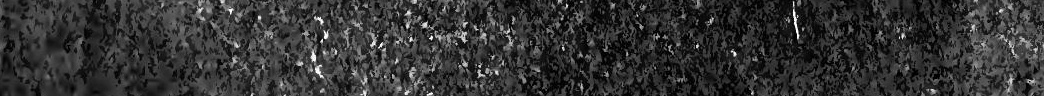

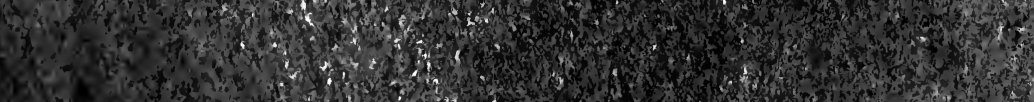
(4)

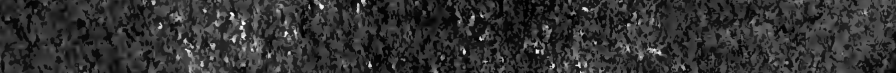

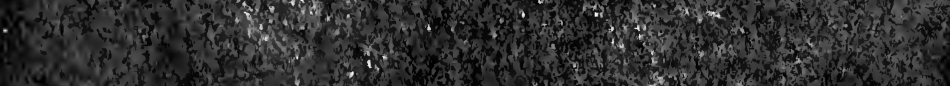

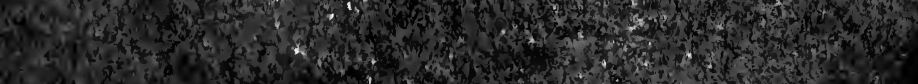

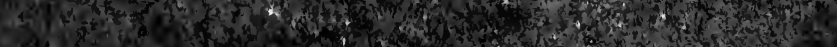

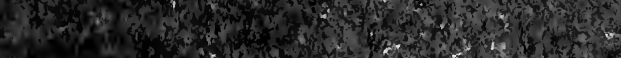

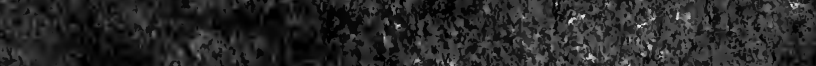

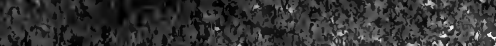





\section{BIOLOGY OF SEX FOR}

\section{Parents and Teachers}

BY

T. W. GALLOWAY, PH. D.

PROFESSOR OF BIOLOGY, JAMES MHLIKIN UNIVERSITY, DECATUR, IIL. AUTHOR OF Elementary Zoology; Text Book of Zoology, ETC,

D. C. HEATH AND COMPANY BOSTON 


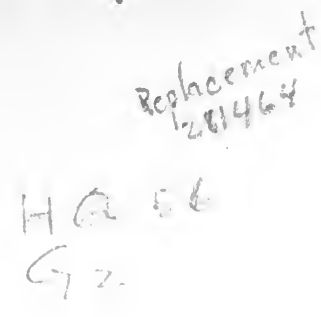

COPYRIGHT, I9I3, BY

D. C. HEATH \& COMPANY

I G 7

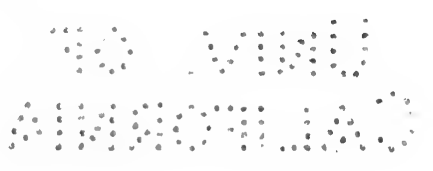




\begin{abstract}
ש0 MY WIFE

AT ONCE MY MOST SYMPATHETIC AND EFFECTIVE CRITIC, - THIS BOOK IS DEDICATED.
\end{abstract}

THE AUTHOR. 
Digitized by the Internet Archive in 2008 with funding from

Microsoft Corporation 


\section{FOREWORD}

When those meet who have given much thought to the question of the need of proper sex instruction for our children, there is little time taken in arguing that such instruction is desirable or necessary at the hands of parents and teachers. The questions which are now being considered by teachers are rather these:- What subjects should be included in this instruction? In what order should they come? Where should the emphasis be put? At what period in the child's life should each topic be presented for best results? Who should do the teaching, and under what circumstances?

In every discussion of the matter, after pointing out what may be done in college and in high school, or even in the grades, by teachers properly equipped with knowledge, earnestness, and insight, the attention is always brought back to the fact that all this comes too late, if nothing has been done before. Before any outside teacher can come to the help of the child, important work must be done by the parent. If sex instruction is to amount to anything worth while, it must begin, and all its foundations be laid, in the home. Furthermore, at every stage in the life of the youth the parents should have a closeness of approach which no one else can gain, and should supplement the work of others at every step.

It is the purpose of the writer in the present book, the material of which was first delivered as a series of talks 
to meetings of mothers and teachers, to bring before parents and teachers some idea of the biological, social, and moral foundations which must underlie all this work and something of the spirit which must characterize it. It is not the purpose of the writer to give in detail all the facts for which a parent may find need. There is an increasing literature in which these may be found.

The problem at the present moment is one of method and spirit rather than of matter;- "how" rather than "what." How can we take the facts, which are easy enough for any adult to get, and use them in such a way as to do good rather than harm to the boys and girls at the various stages of their development? Because the writer believes cordially that there is a sane solution to the problem, and that parents and teachers have, in the phenomena of sex, some most valuable and constructive pedagogical materials, which in the past have been either neglected or used spasmodically, he presents this brief study of the subject.

James Millikin University,

T. W. G.

Decatur, Illinois, June 30, I9I3. 


\section{CONTENTS}

\section{AND SYLLABUS OF CHAPTERS}

FOREWORD

Contents and Syllabus of Chapters

vii

List OF ILLUSTRations

Chapter I. The Actoal Conditions

r. Introduction, r. 2. Increased understanding of the meaning of sex, 1. 3. Two kinds of human facts, 2. 4. The normal up-building values of sex, 3. 5. The destructive and unwholesome aspects of sex, 4. 6. The redemption of the sex idea, 5 . 7. The policy of silence and its failure, 5. 8. The value of sound knowledge, 7 . 9. The limitation of mere knowledge, 7 . Io. Summary, 8.

Chapter II. An Investigation

- I. Introduction, II. 2. The questions, II. 3. The results, 12.

4. Discussion of results, 13. 5. Summary of conclusions, 15.

Chapter III. Some Principles Which Must Guide in Sex INSTRUCTION . . . . . . . . . . . . .

I. Introduction, I7. 2. The first necessity is the "motivation" of the teacher, 18 . 3. Sex instruction must be properly graded, 18. 4. Sex instruction must be different for boys and girls, I9. 5. Sex instruction should follow curiosity, 20. 6. Sex instruction should precede the actual need of it, 2r. 7. Use of the favoring qualities of personality, 22. 8. Sex instruction should be incidental to other teaching, 23. 9. Knowledge of the biology of sex not enough, 24. Io. There must be a sane and wise division of labor in sex instruction, 25 .

Chapter IV. Reproduction and Unselfishness

I. Biology of sex for parents and teachers, 28. 2. The construction of the individual, 28 . 3. Relation of reproduction to this process, 29. 4. Illustrations of reproduction, 30. 5. Further sacrifices growing out of reproduction, 32 . 6. Summary, 33 . 
Chapter V. Sex and Selfishness . . . . . . . .

I. The introduction of fertilization, 35. 2. The introduction of sex, 36. 3. The meaning of the sexes, 38. 4. The attraction of the sexes, 39. 5. The selfishness of sex, 40. 6. Relation between reproduction and sex, 40. 7. These principles applied to human life, $4 \mathrm{I}$.

Chapter Vi. Sex in. Relation to Normal human Physical and Mental Development . . . . . . . .

I. Introduction, 43. 2. The differences between male and female in humans, 44. 3. The relation of sex to these bodily and mental developments, 46 . 4. Relation of sex to the normal development of the human male, 47. 5. The relation of sex to normal development in the human female, 48 . 6. The abnormal aspects of sex in human beings, 48. 7. Special abuses of sex in men, 49. 8. The abnormal aspects of sex in women, 52. 9. Summary, 56.

Chapter VII. The Social and Moral Bearing of Sex . . . .

I. Résume of the relation of sex to mental life, 57. 2. Sex and social life, 58. 3. Abnormal influences of sex in society, 59. 4. The moral bearings of sex, 62. 5. Human standards to protect social morals, 63. 6. The inner personal morals, 63. 7 . Incentives leading to self-contral, 65. 8. Sex and religion, 67 . 9. Summary, 68.

Chapter VIII. Time and Manner of Instruction . . . .

I. Introductory, 69. 2. The matter of instruction, 69. 3. The periods of the child's life as they relate to sex instruction, 70 . 4. The early stage: from birth to 4 or 5 years, $7 \mathrm{I}$. 5 . The early stage: from 4 to 6 or 7 years, 72 . 6. The prepubertal stage: from 7 to ro or II,72. 7. The pubertal stage : from Io or II to I4 or I5, 74. 8. Post-pubertal or late adolescent stage : from $I_{5}$ to $I 8$ or 20, 76. 9. Summary, 78 .

Chapter IX. Eugenics

r. Introduction, 79. 2. The essential contention of the eugenist, 79. 3. The things that influence birth, 8I. 4. Hereditary transmission of taints, 82. 5. Congenital infections, 83. 6. Social or economic incapacity, 84. 7. Relation of these considerations to human marriage, 84. 8. Other reforms made necessary by these facts, 85 .

Appendix. The Problems of Parents

r. Questions of early childhood, 90. 2. Special problems of adolescent boys, 97. 3. The problems of the adolescent girl, IOI. 


\section{LIST OF ILLUSTRATIONS}

FigURE I. Reproduction by simple cell division (Paramecium) . . 30

FIGURE 2. Reproduction in simple cell by budding (Yeast) . . . 3 I

FIGURE 3. Reproduction by budding in many-celled organism . . 31

FIGURE 4. Many-celled organism reproducing by similar, one-celled offspring (Spores) . . . . . . . . . . . 32

Figure 5. Many-celled organism reproducing by similar, one-celled offspring which unite (Gametes) . . . . . . 36

Figure 6. Reproduction in which a single parent produces two kinds of offspring, - eggs and sperm . . . : 36

FIGURE 7. Reproduction in which the male parent produces one kind of offspring and the female parent another kind. . . 37

Figdre 8. The sex glands and ducts in the male. . . . . . 50

Figure 9. The position of the pelvic organs in the female; side view 54

FIGURE Io. The relation of ovary and uterus; ventral view . . . 55

FIGURE II. Flower of lily (Section) . . . . . . . . . 95

FIGURE I2. Fertilization in the lily . . . . . . . . . 96 



\section{BIOLOGY OF SEX FOR PARENTS}

AND TEACHERS 



\section{BIOLOGY OF SEX}

\section{CHAPTER I \\ THE ACTUAL CONDITIONS}

1. Introduction. - A new book on a subject like this must first justify its existence to the reader. This chapter undertakes to do this. In the meantime the writer wishes to make a few simple statements of fact for the encouragement of the serious reader.

(I) The problem of sex, as it bears on human education, conduct, and welfare, is one of the most practical and important that we are called on to solve.

(2) On the whole it has been the most neglected, ignored, and abused side of our human education.

(3) There is now on foot a very definite and promising movement among educators, social workers, and other thoughtful people to take up the problem in a scientific and humane way. This is one of the most hopeful educational movements of the new century.

2. Increased Understanding of the Meaning of Sex. During the last seventy-five years science has been discovering the principles that have made it possible forourinventors to construct the telegraph, the telephone, the phonograph, and other devices that mean so much in our material progress. In just the same way, science, working with the 
principles of life, has shown us the great part that sex has played in all the life of the earth, including that of man. Because of this knowledge of .sex, and by means of it, the plant breeder has produced wonderful new and improved varieties of fruits, grains, daisies, and roses. By means of the same knowledge, the animal breeder has produced a marvelous improvement in all the domesticated animals. Thus, through the biologist, we have learned that there is no more universal and important thing in life than the matter of sex and reproduction; and, through the practical work of the breeders of plants and animals, we are learning to ask the question whether we can not use this knowledge in such a way as to improve human life, quite as much as we have improved the character of roses and chickens.

3. Two Kinds of Human Facts. - In the past those educators and reformers who have worked at this problem have been inclined to dwell on the degrading, abnormal, destructive side of the question, as though this were the whole of it. The great social vices and diseases that have blighted civilization throughout human history are indeed important things. They are fearful to contemplate, and form a most serious and menacing problem. They are not, however, the real problem which the human student of sex must keep before him, any more than the army hospital and caring for the wounded is the real problem of a commanding general in warfare; or than crime and treatment of criminals is the real problem of progressive civilization. Disease is not the chief problem of life; sound, wholesome living and growth are the real problem.

Any study of this matter of sex, then, which pretends to 
have any permanent and constructive value, must take care of two aspects of the matter - (r) the deep, fundamental, natural, positive, stimulating, upbuilding rôle of sex in human life; and (2) the abnormal, destructive, and dangerous perversions that are such a blot on our human history. Deeper still, a student of this problem must find out the biological and social connections between the normal and the abnormal, and bring the whole of it to bear on the proper education of young people.

\section{The Normal, Up-building Values of Sex. - It must} be understood, at the very beginning, that sex and all that it implies is a perfectly, natural, normal fact of life, with nothing unholy or perverse about it. It is true that the sex impulses and desires are very powerful; but to the biologist this is just a sign that they are very important in life. As will be seen later, sex is responsible for certain great principles of growth and development in all organisms, from the lowest to the highest.

Without stopping at this point to go into details, we know that the differences between men and women, - in body, in mind, in disposition, in temperament, - are not just mysterious, created differences; but are the direct result of the development of the sex nature of the individual. Just to illustrate what a wonderful and vital influence sex has in life, one only needs to remember that all that is meant by the following words grows out of sex and its results, - manliness, womanliness, love, courtship, marriage, home, father, mother, family life, parental care and education, filial devotion, brotherhood. These facts, ideas, and relations, - and the human virtues that grow up in connection with them, - could not have existed but for that which 
we call sex. These are the normal and natural fruits of sex. Such fine and beautiful fruits cannot spring from something essentially bad and unholy. Undertake to remove from our lives and minds the ideas and facts for which these words stand, and nothing worth while would be left in human civilization, history, literature, poetry, or happiness.

\section{The Destructive and Unwholesome Aspects of} Sex. - While it is true that we must come to know that the above-mentioned qualities and relations are the natural and most important facts of sex, and that the abnormal is the exceptional, - it is also true that the abuses of sex are great and deep in their evil effects. The abuses, diseases, and immoralities of sex are the most distressing of all that confront the modern helper of humanity. Merely to mention the great contagious sex-diseases and the inherited troubles that come from them, the numerous children born out of wedlock and the personal and social disgrace and grief occasioned thereby, public prostitution, the white slave traffic and all the loathsome immoralities and heartlessness that cluster about it, and the wrecked lives of many boys and girls, is enough to convince anybody that too much cannot be said, nor too much done to help the race purify these ancient evils. These must be studied by reformers, must be preached against by preachers, must be fought against through legislation by all statesmen who love their kind, must be met and fought by parents and teachers. But, terrible and prevalent as these perversions are, they are none the less perversions. All our study and effort will be hindered if we forget for a moment that the thing perverted is bigger and more important than the 
perversion; that the normal, rather than the abnormal, is basal; and that knowledge of disease and its cure depends on the understanding of the fundamentally healthy structure and function.

6. The Redemption of the Sex Idea. - It is because of the facts noted above that the recent movement to educate all, especially the young, in the problems of sex seems so wise and sane to thoughtful teachers and social workers. This education involves the idea that we accomplish two things. We must restore the thought of sex to its real biological place, as a wonderful, vital, stimulating and holy endowment of human life, to be treasured and invested as we treasure bodily health, mental ability, and attractive disposition; and in doing this we must cease to think of the facts of sex and its desires as vicious and depraved, and as. shameful elements in life, to be avoided or ignored or abused. Only when we grasp the whole of the problem, with the constructive as well as its disastrous possibilities, can we use it as a real part of human education and inspiration. The word sex must come to mean to us fine and high things rather than bestial and low, before we can afford to bring it to the education of our children.

7. The Policy of Silence and Its Failures. - For many years there has been a prejudice against any real education of young people in the great underlying facts that have so much to do with our development and social relations. Parents have neglected to treat the matter in a serious and straightforward manner with their boys and girls, and have been unwilling to allow the schools to do so. Teachers have felt that it was the duty of parents, if of anybody, to do this work. Text-books, to which the subject naturally 
belonged, have carefully avoided any mention of the matter, or out of respect to these prejudices have touched upon it in the most superficial and apologetic way. Physicians have given no help until too late, when disease or fear of disease and social disgrace, has brought the young people to them.

The reasons for this silence are largely (I) cowardice, (2) ignorance on the part of parents of the facts and of the best way to present them, and (3) an easy-going creed (arising largely from both cowardice and ignorance) that it is better to keep children in ignorance of such things just as long as possible, that innocence and purity belong to this ignorance, and that knowledge of the facts of sex must bring hurtful results. There are two important fallacies in this line of behavior which make it both futile and criminal. In the first place, ignorance of fundamentally important facts in life cannot, in the long run, help to meet those facts in the most satisfactory way. In the second place, parent and teacher have not the choice between ignorance and knowledge of this subject, in the child. The only choice is between the incomplete and distorted information that may be picked up from companions, and the sound, accurate knowledge given by those who know; between secret and open knowledge; between suggestive knowledge given in impure and vulgar ways and clean, pure information, graded step by step to the needs of the child as it advances, and connected in the child's mind with the great normal human values. The sex-impulses are too powerful, the facts of sex are too wonderful and too widely known, and human curiosity is too great for the policy of silence to secure its end, even if ignorance were best. The very conditions that make it 
certain that children will get some sort of knowledge make it necessary that they should have it in the best possible form. They need it and are entitled to it.

8. The Value of Sound Knowledge. - One of the values of sound knowledge is that it displaces half-knowledge and false knowledge, which are the very worst sort of ignorance. But deeper still is the fundamental confidence and optimism about the order of the universe which says that truth is always better than error, and that knowledge of truth is a first essential -step toward ordering one's conduct aright. It would need to be a very haphazard universe before ignorance could guide as well as knowledge. Knowledge may of course not cause us to do right; but ignorance of facts can never secure conscious rightness of choice. It is conceivable that occasionally ignorance might save a weak individual; but where one person is saved by ignorance, thousands are lost through ignorance and inaccurate information. Thus it has come about that the modern educator feels that the right knowledge of sex is more likely, in the long run, to help than to harm, - and is infinitely better for the salvation of youth than the vulgar half-knowledge derived from slightly older companions.

There is one other point to be mentioned. It is probably true that information given by parents and teacher may have a stimulating effect and make the child want to know more; but for that matter the partial knowledge the child gets from its companions does the same thing, and makes it even more morbid.

9. The Limitation of Mere Knowledge. - No educator, who has observed carefully and has given serious thought to his observations, will claim that it will solve all the prob- 
lems of sex and sex relations merely to impart to youth in a perfect way all the facts of sex and its place in human development. The teaching of the facts and hygiene of nutrition has not eliminated abuses of digestion among us; but who is prepared to say that the teaching of the hygiene of eating, the new "domestic science," and the agitation for pure and uninfected foods, do not produce year by year their effect in increasing the proper use of foods?

We know that knowledge - even perfect knowledge will not successfully meet the case. There must come in addition, through the sanest sort of teaching, - as in all such realms of human character and behavior, - ideals, standards of purity, chivalry, regard for others, selfrestraint, and all such things, which are better than mere knowledge. But into all of these knowledge must go; and there is no firmer foundation for these clean motives $\checkmark$ than a pure and wholesome knowledge of all the facts.

It is true that mere knowledge does not insure right conduct in any department of life; but there is a correlation between knowledge and right conduct. That is to say, a larger percentage of individuals who know the facts in a given situation make right choices than of a selection of informed and ignorant persons, made at random. This has been worked out experimentally in respect to a number of human relations, and has been found to be true in practice.

10. Summary.-Three very different streams of human influence have been operating to convince us of the need for real education in regard to reproduction and sex. First among these are the reformers, sensitive to the hideous 
aspects of the social evil in its various forms and to the moral degeneration that accompanies the perversions of sex. Their point of view, though urgent and compelling, is narrow and partial, since it deals with the abnormal and destructive rather than with the constructive; their work, however, has aroused our consciousness of the problem.

In the second place, a certain group of students has approached the question from the purely biological and scientific side. Their interests have centered in the possibility of race improvement through better breeding, through heredity. These students are called eugenists. They are not moved, primarily, by sensitiveness to social and moral abuses of sex. They think rather in terms of the loss of present and future social and industrial efficiency through the hereditary transmission of incompetence and of criminal tendencies. This scientific contention has played a large part in arousing our interest in sex instruction, and greatly broadens the scope of it.

Thirdly, students of education have been coming to realize that reproduction and sex are among the most important human functions; that the impulses connected with them are as natural and clean as any we have; that these impulses are both general and powerful; that their power is a measure of their importance in the life of the race and of the individual; that they underlie and give character to all social conditions; and that such vital qualities cannot fail to be useful in educating normal human beings if we but learn how to use them aright.

The reformer would educate in respect to the facts of reproduction and sex, in order that youth may be pure and may escape vice and the personal and social diseases that grow out of it. The eugenist would educate in this field in 
order that we, as a race and as individuals, may secure better matings and more perfect offspring and thus build up the stock. The educator would seek to use the facts, instincts and impulses of reproduction and sex in their due course, in order to stimulate the right and sound personal and social development of the individual. 


\section{CHAPTER II}

\section{AN INVESTIGATION}

1. Introduction. - Following a series of perfectly frank talks by the writer, first to college men and later to college women of the Christian Associations, an effort was made to get the opinion of the young people with respect to certain points. A brief series of questions was arranged, and the students were requested to answer them. The answers were not signed, were entirely confidential, and were left wholly optional with the students. There were ninety-six answers from the young women, and seventy from the young men. These students represent quite normal college young people, undoubtedly from the rather better classes of homes. The statistics are believed to be fairly representative of conditions in the average homes of the grade represented. Doubtless other inquiries, and a larger number of individuals would show somewhat different percentages in the different groups; though the main conclusions are so pronounced that it is inconceivable that more extended testimony would largely change the results.

2. The Questions. - The following were the questions asked:

I. At about what age was the subject of sex first brought in a striking way to your consciousness, that is, in such a way as to make a permanent impression?

2. Through whom was it thus brought? 
3. What, in general, was the effect of the information upon you, as you look back on it now?

4. Indicate, if you are willing, in what way this infor-i mation was good or bad for you, as the case may be.

5. Do you think that fuller and more authoritative information, given in the right spirit, would have been of any help to you?

6. If so, in what way?

3. The Results.-The following is a tabulation of the answers:

\section{Question I}

TABLE I. MEN (70)

\begin{tabular}{c|c|c|c|c|c|c|c|c|c|c|c|c}
\hline \hline Age (years) & 6 & 7 & 8 & 9 & I0 & II & I2 & I3 & I4 & I5 & \\
\hline Number . . . & 4 & 9 & 8 & 8 & 8 & 3 & II & 3 & 7 & & 2 & $\begin{array}{l}\text { (remainder } \\
\text { uncertain) }\end{array}$ \\
\hline \hline
\end{tabular}

TABLE 2. WOMEN (96)

\begin{tabular}{c|c|c|c|c|c|c|c|c|c|c|c|c}
\hline \hline Age & 6 & 7 & 8 & 9 & I0 & II & I2 & I3 & I4 & I5 & I6 & I7 \\
\hline Number & 2 & 6 & 8 & I2 & I0 & I0 & I8 & I5 & 9 & 4 & 2 & I \\
\hline
\end{tabular}

Questions 2 and 3

- TABLE 3. MEN

\begin{tabular}{|c|c|c|c|c|}
\hline \multirow{2}{*}{ Through Whom } & \multirow{2}{*}{ Number } & \multicolumn{3}{|c|}{ Effects } \\
\hline & & Good & $\mathrm{Bad}$ & None \\
\hline Boy Companions & 47 & I & 32 & 4 \\
\hline Parents . . . . . & II & 9 & & I \\
\hline (Quack Doctor . . . & $\mathbf{I}$ & & $\mathbf{I}$ & \\
\hline Older $\{$ Family Doctor . . . & & 2 & & \\
\hline Men ( School Teacher... & I (in & ss) & I & \\
\hline Y. M. C. A. pamphlet . . . & I & $\mathbf{I}$ & & \\
\hline
\end{tabular}


TABLE 4. WOMEN

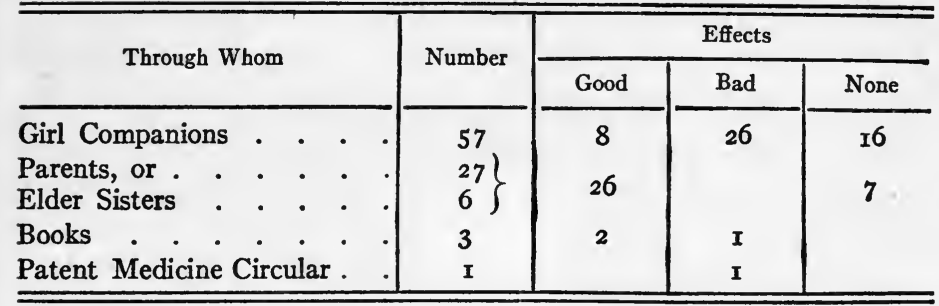

Question 5

TABLE 5

\begin{tabular}{l|c|c|c}
\hline & Yes & No & Doubtful \\
\cline { 2 - 4 } Men & 46 & I & 6 \\
Women & 60 & 7 & 3 \\
\hline \hline
\end{tabular}

4. Discussion of Results. - Tables 3 and 4 show very clearly that both the young men and young women think that the information that came to them from their mates did more harm than good; and that the information that came from their maturer friends with wholesome purposes helped them. Table 5 shows very general agreement that more and better information would have helped them to solve their individual problems to better advantage.

By comparing tables $I$ and 2 it will be seen that $5^{8}$ per cent. of the boys, who gave the age at which they received instruction, learned enough of these matters to make an impression on them before they had completed their tenth year; whereas only 50 per cent. of the girls had received it by the close of their eleventh year. Thus the boys are more than a year ahead of the girls in getting at these facts, in spite of the fact that girls mature more 
rapidly than boys. This is exactly what we should expect from our knowledge of the manner of life among boys.

A comparison of the ages at which information was received with the sources from which it came shows that in nearly all the cases (forty-four out of forty-seven) in which boys got their information from their mates, it came at an early age. Parents gave information to their boys as follows: two at eleven years; two at twelve; two at thirteen; four at fourteen. The same conditions are found for the women, but not quite in the same degree; mates among the girls were a little more reticent, and mothers a little more prompt in performing their duties than the fathers. A considerably larger percentage of the women got help from mothers and older sisters, than of the young men from their fathers.

The answers to the fourth question as to ways in which information proved helpful or hurtful are not quite-so definite nor so capable of tabulation; but they are very illuminating. The young women were more disposed to answer the question than the young men. Of those who thought the early information from mates was hurtful, six thought it created a morbid interest in the subject; ten said it caused them to dwell on the subject and take a wrong attitude toward it; eight said it gave them false ideas; others said it "caused shrinking, depression, and unhappiness," "was improperly given," "not pure," "feared to go to mother about such things." Among the answers of those who got their knowledge from better sources and thought that it had helped them, the following are representative reasons:- "It produced a strengthening of principles," "recognized need of careful action," "led to preserva- 
tion of health," "brought content, and freedom from dwelling on it," "better attitude," "made life seem more beautiful and sacred."

These answers are so sane and so clearly what an observant educator would expect the facts to be, that one has no difficulty in believing that they really represent the personal convictions of the writers.

While there were exceptions, the overwhelming conviction of these young people was that better information, from the right people and given in the proper way, would have been of much value to them both in their attitudes and their actions. Of course, it is quite natural for us to think that we might have done better if we had possessed more knowledge; and it is not always true that we should have done so. On the whole, however, these are the separate judgments of people who are in the best position to know what would have influenced their lives, and how. While the answers are not scientifically conclusive they have a distinct presumptive value.

5. Summary of Conclusions.-An inquiry among a thoughtful group of mature young people, who probably represent homes and parents above the average, reveals definitely the fact that only about 20 per cent. of the fathers and about 30 per cent. of the mothers had made an effort to reach these young people with sound information about this most important influence on their bodily and moral welfare. The general average of homes would undoubtedly be much less than this. The chief training which comes to the minds of the young is the inaccurate, morbid, vulgar training of mates, which is unquestionably worse in its effects than ignorance. 
It is very clear that, if parents and teachers are to get to the youthful mind first, and establish an open and pure channel for sex knowledge, they must approach children much earlier than they are doing at present and continue their teaching systematically at all points where it is needed. 


\section{CHAPTER III}

SOME PRINCIPLES WHICH MUST GUIDE IN SEXINSTRUCTION

1. Introduction.-In the two preceding chapters an effort has been made to justify, first in theory and then by a concrete example the view of the modern educator that the best equipped people in the community should undertake the task of giving our children adequate sex-instruction. This instruction should enable them to avoid the pitfalls that beset them at various crises in their lives; and, what is still more important, should inspire them with an idea of the far-reaching influence of sex as one of the most powerful impulses and characteristics in human life. In this chapter it is purposed to anticipate some things which will be treated at greater length later on; here, however, in a brief and somewhat dogmatic way, will be put down without argument certain conclusions that seem to be justified from our general knowledge of education and of the methods that have proved successful there. The effort to provide systematic sex-education is new, and until more experiments have been conducted and the results reported we cannot be absolutely sure of the best methods to be followed. We cannot, however, afford to withhold all sex-education, if we are right in contending that it is essential, until the way has been completely surveyed and charted. We must start with the best principles we know, and correct them as they are shown to be imperfect. 
2. The First Necessity Is the "Motivation" of the Teacher.- It is a common experience that reforms, or educational movements of any kind, do not progress until the rank and file of those who must do the work become thoroughly convinced as to the necessity and possibility of moving. Our teachers, whether parents, school-teachers or Sunday-school teachers, physicians, or ministers, will not take up this delicate and difficult work until they have an overpowering conviction of its necessity and value to humanity. Among teachers, the act of arousing in their pupils purposes and motives that will produce action is called "motivation." This is what teachers themselves need now in respect to sex-education. To bring home to parents and to other teachers this conviction of the duty of giving sex-instruction to the young, and to inspire them with the interest and motives that will induce them to undertake this duty is the first task of those who are themselves convinced of the importance of the subject, as well as being one of the greatest necessities of the present day.

Among students of the question, as has been intimated, the more alert teachers and parents are beginning to feel that something must be done; but for the most part, even the best teachers are generally feeling that the first responsibility rests with some one else. The motivation of teachers and parents must become complete and personal. It is the purpose of this book to assist in the task.

3. Sex-Instruction Must Be Properly Graded.- If it is important to grade our instruction in English and mathematics and adapt them to the capacity of the child it is doubly necessary to grade instruction in sex. Instruction in English and mathematics seeks information chiefly, 
while sex-instruction seeks to influence attitudes of life and conduct. It is always a more delicate and difficult task to mold conduct than to impart knowledge. It is for this reason that instruction in sex should be most carefully and accurately graded.

Grading in sex-instruction includes the following points:

(I) It should be different for boys and girls.

(2) It should be guided by, and follow, the progress of the natural curiosity of the child, and not precede it.

(3) It should precede, at each step, the actual personal needs of the child and youth in respect to life and conduct.

(4) This teaching should be adjusted to, and take advantage of, the fact that the development of children offers certain favorable conditions for certain parts of the necessary teaching.

(5) There should never be an idea that all necessary instruction can be reserved until the child is thirteen or fourteen and then given all at once.

\section{Sex-Instruction Must Be Different for Boys and} Girls.- There is much that is common in the information that should be given to boys and girls, and each sex should in time know and appreciate the main facts about the development of the other; yet the sex development and the impulses of the two sexes are so different and the special practical problems that confront the boy and girl are consequently so unlike, that the material and the point of view must be properly suited to the peculiar nature and needs of each. This makes it necessary that boys and girls shall be taught separately in these matters, - though this is probably not necessary in the broad, impersonal studies 
of the question undertaken in the classes in physiology and biology. There are teachers, however, who believe that better results are possible, even in these classes, if only one sex is present.

We all know that the sex impulses of males are strong and violent as compared with those of females; hence the problems of the boy are largely problems of self-restraint, while, on the other hand, the problems of the girl are rather those of resistance of external temptation to do wrong, and of behaving in such a wise and discreet way that no such temptation will arise. These differences in the nature of the sexes lie at the bottom of all our efforts to educate, and must have a large part in molding the character of our teaching and the method of it, if we are to get from it such real personal results as we seek to achieve.

5. Sex-Instruction Should Follow Curiosity.-Curiosity, in its broadest sense, is the chief internal thing that drives us to seek knowledge. The desire to know is at the back of all our investigations. Curiosity begins early in the life of the child, and is responsible for the great progress that is made during the first years of life, - a much more rapid progress than we ever make at any subsequent period. The wise educator of youth tries to take advantage of this natural curiosity, to keep it alive, to increase it, to guide it, and to prevent it from becoming morbid and narrow. In matters of sex the problem is, not to increase curiosity, but to prevent it from becoming unhealthy and morbid. If not enough information is given, the mind is likely to dwell on it and to wonder; if too much is given, so that the child is unable to understand or assimilate it, practically the same results follow. 
If the parents take an open and frank attitude toward the little child in the home, the active curiosity of the child, as shown by its natural questions, indicates at what intervals information should be given and how much should be told. This is especially true of younger children, who are much with their parents. If this curiosity does not express itself spontaneously, the parent, by a little discreet questioning, can readily find out the state of the child's mind. If, when the child seeks information, it is withheld or is given falsely and evasively (as is so often the case) the child will very naturally lose some of the confidence which the parent should make every effort to hold, and will go elsewhere to get his questions answered. If, on the contrary, the parent, at the first question, gives the child a mass of facts for which he is not prepared and for which he has felt no need, the child will be confused and unable to profit by the knowledge. Both sets of results are unwholesome. The best teaching rule is: follow curiosity closely, with carefully graded information.

\section{Sex-Instruction Should Precede the Actual Need} of It. - The strong point of the modern plea for sex-education is that it is badly needed. If this plea be true, it follows that the needed information, to be of value, must be received and assimilated by the child before the critical points appear that make the information necessary. This need furnishes the only exception to the preceding rule. In the case of children of a certain disposition, or of those who have been peculiarly sheltered from contact with the facts of life, it may be true that curiosity will not be alert; or it may sometimes happen that the parent will know of some approaching sex crisis that the child has not asked about. 
It may be in such cases the duty of the teachers, - parents or others, - to arouse curiosity and give the needed help.

For example, it is important that the child of either sex should know beforehand the real nature of some of the bodily and mental changes that come at the age of puberty. This is peculiarly necessary for girls, in order that they may take proper precautions to protect themselves from the lung troubles that often follow exposure during menstruation, in girls under twenty. Similarly, the awkwardness of boys, their change of voice, seminal emissions, and the like, would not produce the embarrassment and mental distress which they do, if the boys knew that these are perfectly natural steps to manhood. The physical, mental, and moral catastrophes so frequent at this period are largely preventable if the child can be made acquainted in a general and inspiring way, with the nature of the facts and their meaning.

7. Use the Favoring Qualities of Personality.-We have learned that all the elements that go to make up our personal character do not begin nor mature at the same time. We have seen above that curiosity comes early in life and stays with us long. On the other hand, there are certain periods in our childhood growth when certain characteristics and states of mind dominate us, only to decline later and give place to others. Some of these states favor one kind of method of sex-instruction, and other states demand some other method. It is necessary to good teaching to know something of the succession of these qualities and impulses of youth and to use them to reinforce our instruction on sex, just as wise teachers are using them in other sides of education.

For example, the strong bond that usually exists between 
the young child - whether boy or girl - and the mother; the growing boy's admiration for his father; and the chivalrous spirit which comes to normal boys in late adolescence when they begin to admire the girls,- - are all illustrations of what is meant. These all make certain steps in the sound education in facts of sex and sex ideals peculiarly possible and timely. There are many such critical points in individual development when special appeals should be made, appeals which would not have equal weight either before or after. These facts will show how mistaken is the practice of some parents, who keep back all they have to say until some convenient time and then try, with no special relation to anything that they know of in the child's life, to tell all they think should be known. It would be more sane to adopt this method in teaching mathematics than in giving sex information.

\section{Sex-Instruction Should Be Incidental to Other} Teaching.- - One of the main errors of parents and teachers in dealing with this topic, lies in separating it from other teaching so as to make it stand out unduly. In reality the facts of sex are in nature closely related to the other facts of life. Sex teaching that corresponds naturally and incidentally to events that are occurring in the home, the farm, or the community, or is given in connection with other lessons in school, will have a more natural and less disquieting effect, as a rule, than that which is given separately and independently in the form of a lecture or talk.

It is much better, for example, to connect the early teaching of the child concretely with the birth of a baby in the 
home or neighborhood, or with the birth of pets, than it is to deal with it as a general or abstract truth.

Furthermore, much of the instruction which will lead to proper ideals and behavior in relation to sex, need not be called sex-instruction at all. Chivalry, respect for women, the meaning of the home in the organization of society, and many other topics which serve to give right views of life can do their work without any conscious attempt to denote them as a part of the sex problem. Yet they are none the less a part of it, and teachers should realize this fact.

9. Knowledge of the Biology of Sex not Enough.There is a tendency on the part of some enthusiastic people to think that a thorough knowledge of the facts of sex will meet all the needs of the young. There is no doubt that this biological information is the foundation, and that such knowledge will greatly enlarge and purify the child's ideas of reproduction and sex. But this is not enough. We want our children to be healthy animals, but we also require of them behavior quite different from that of the healthy animal. We want them to get a knowledge of sex, but to get with it such a disposition that they will have within themselves something which will control and guide the powerful sex-impulses in the interest of all the fine and holy ideals they have built up. To do this, mere biology is not enough; we must have in addition all the help that we can get from those kindred fields of human inspiration and discovery which we call psychology, sociology, ethics, and religion. The child must know the meaning of sex; he must know what are the best standards of the race about the use of sex; he must be willing to choose to use it in 
accordance with these standards; and he must have the internal power of character which will enable him to carry out this choice in his conduct. He cannot reasonably be expected to attain this disposition in ignorance and without expert help.

\section{There Must Be a Sane and Wise Division of Labor} in Sex-Instruction. - If we may hold that the principles laid down in the foregoing paragraphs are reasonably true, we have a few groups of people whom society must make responsible as classes, for this work of sex-education. Chief among these are parents, school-teachers, Sunday-school teachers, social workers, physicians, and ministers. In individual cases, there may be persons better fitted than any of these to do the needed work; but generally speaking, the above classes of people, rather than youthful mates or vulgar-minded servants, must assume the task.

(I) Parents are, or should be, much the best fitted of all these by their natural position and close relation to the children. This is particularly true of younger children, of whom the mother is the natural instructor. On the other hand, parents are usually the least fitted by information and training to do this work in the best way.

(2) The physician is possibly best fitted of all in the knowledge of the facts; but his opportunities are not sufficient and usually his knowledge of the proper methods of teaching is poor.

(3) The public-school teachers are best prepared of all in the knowledge of methods of teaching, and next to the parents themselves have the children in their direct care. Most of these, however, lack information, just as parents 
do, as to the exact facts which should be given and the possible results of these facts. Furthermore, they have to teach the children in such numbers that another very difficult feature is introduced. In somewhat the same plane, but with less opportunity, come the Sunday-school teachers.

(4) The other classes mentioned have some opportunities; but are for various reasons limited in what they can do directly. For example, athletic directors in Christian Associations can render special service to adolescent boys and to young men, as can these directors in high schools, colleges, and universities.

It is probable that the teachers will be the first of these groups to be aroused to do their proper part. There are those who believe that we cannot rely on parents at all and must depend almost wholly on the schools. This, however, neglects the truth that the time of starting to school is too late for some of the simple facts which children must know, if they are to come from pure sources. In the opinion of the writer the mothers will be inspired and educated by the teachers to give the children the instruction they should have before school age, and to assist the teachers in guiding their development beyond that time.

Physicians can assist the movement by appropriate lectures to teachers, parents, and nearly mature young men and women, giving the technical facts which bear on their various problems. In a similar way, ministers who are sufficiently informed can present to the community the social and moral bearing of the work.

The accompanying scheme will at least suggest a general division of responsibility suitable to the average community. 
SCHEME SUGGESTING DIVISION OF LABOR AND LOCATION OF RESPONSIBILITY IN SEX-INSTRUCTION

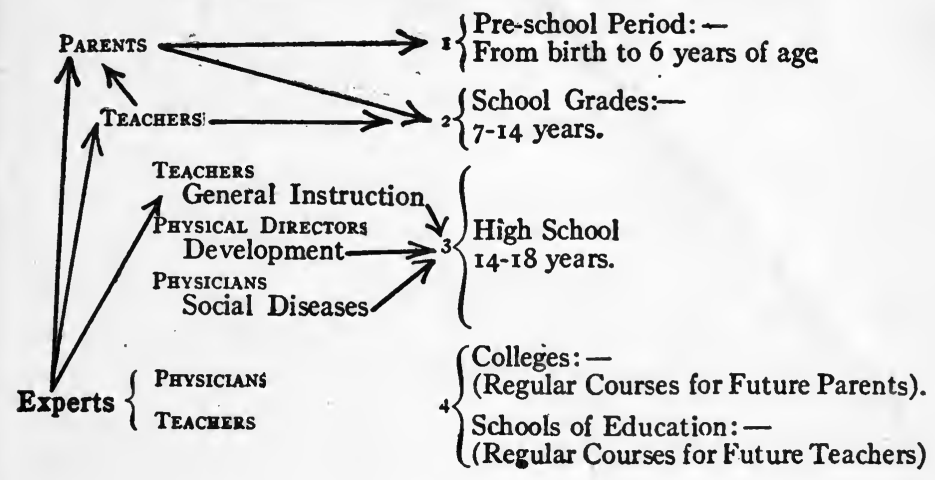




\section{CHAPTER IV}

\section{REPRODUCTION AND UNSELFISHNESS}

1. Biology of Sex for Parents and Teachers. - We have concluded that society rightly places on parents and teachers a large part of the responsibility for educating the rising generation so that sex may be an inspiration and a blessing rather than a blight. If this conclusion is right, it follows that these leaders of youth must be acquainted with the broad biological facts, in order that they may have a background, as well as with the details of human development, in order that they may meet particular cases. In a brief discussion such as this it is impossible to enter into all the details of what shall and what shall not be taught, even if we knew. The purpose of the present book is rather to give to the parent and teacher some information about the fundamental biological principles which we must respect, accompanied with outlines of the general kinds of knowledge that the pupil should have. With these in mind the teacher will be able to seek successfully the special facts that may be of most service.

2. The Construction of the Individual. - No matter how simple or how complex is the individual, the building up of its life is much the same. The one-celled plant or animal, in order to be successful, must take just about the same steps as an oak or a man. It must begin its life, it must be nourished; it must grow and protect what it gets; it must upbuild itself through its own powers, desires, and 
appetites. In one way or another, all these things look toward getting, toward an income for the individual. They may be described in a word as selfish - because they minister to self-construction. There is no purpose to suggest that these selfish qualities lack in fineness or dignity, merely because they are selfish. They are at the very foundation of successful individual life, and the later qualities would be quite impossible without them. The natural, normal result of these basal things, when allowed to have full sway, is to produce sound, healthy, self-centered individuals. This we may say is the first and most important power of living things, and the higher powers depend on it.

3. Relation of Reproduction to this Process. - Somewhere at the climax of this emphasis on the self, even in the very simplest organisms, there comes a complete reversal of the behavior of the organism. In some way or other, by a process that may seem quite simple or may be very complex, the old individual, whose whole energy hitherto has been given to building itself up, divides. In this way the substance so carefully brought together is distributed to two individuals. (See Fig. I). This process is called reproduction. It is easy to see that it is just the opposite of the self-building processes described before. It divides up and scatters the living matter at the expense of, and often with the complete destruction of, the original individual. This represents outgo where the former process meant income; this means extending the species where the other meant strengthening the individual; this means selfsacrifice where the other meant self-seeking. Biologically speaking, reproduction is next in importance to, and just as universal as, nutrition and growth, and is directly opposite 
to them in nature and results. This description is a brief picture of all life, which consists of a period of selfish growth in which the individual is built up to its maturity, followed by a period of unselfish reproduction of new individuals, which must in their turn grow and mature.

4. Illustrations of Reproduction. - While it is impor-
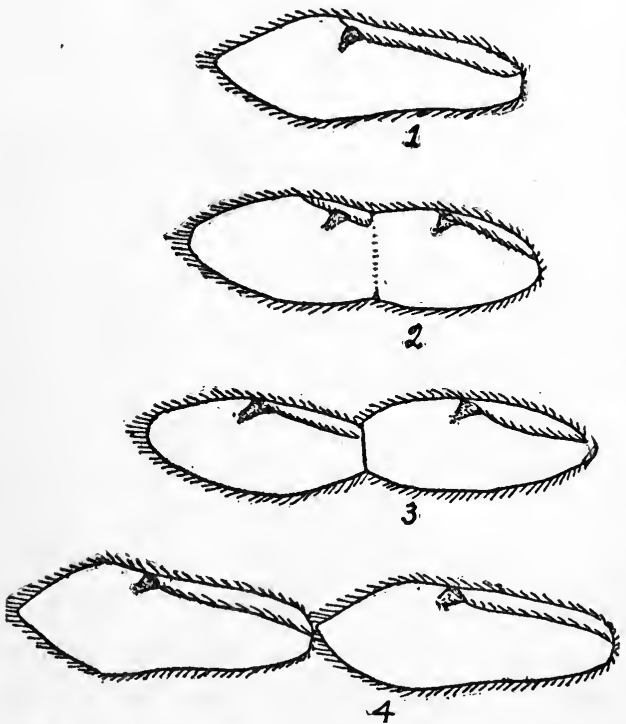

Fig. $I$. Reproduction by simple division in a single-celled animal (Paramecium): $I$, an adult organism; 2 , the same in process of dividing into two daughter organisms; 3 , a later stage of the same; 4 , the two daughter animals mature. The sacrifice of the mother cell is complete here.

tant to remember that all reproduction means sacrifice of the individual, the form and degree of the sacrifice differs in different kinds of organisms. The accompanying di a gram s will help the reader to appreciate something of this difference.

In Fig. I, we have a simple organism that grows to its full size (I) by the process of nutrition; and after a period it divides (2) into two equal, half-sized offspring just like the parent except for size. These grow to the size of the parent (4) and the process is repeated. In this case neither of the resulting offspring can be called the parent; the parent is completely 
sacrificed in the act of reproducing. The mother cell has given its life for the two daughter cells.

The sacrifice is not usually so complete as this. In Fig. 2 we have a scheme by which the parent can produce one or more smaller members of its kind without be-
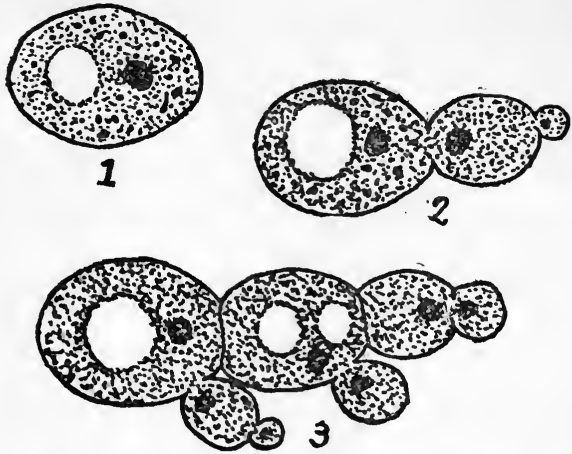

Fig. 2. Reproduction by budding in a single-celled plant (Yeast): 1 , an adult cell; 2 , and 3 , stages in budding in which new outgrowths from the mother cells produce daughters. These grow up and may become independent or remain attached in a chain. The sacrifice of a mother cell in this case is not complete.

ing completely destroyed in doing so. Reproduction in this case merely checks the individual, selfish processes of the mother, temporarily. This is also a kind of division, just as in Fig. I; reproduction is always division. This, however, is more economical, and leaves the parent in such

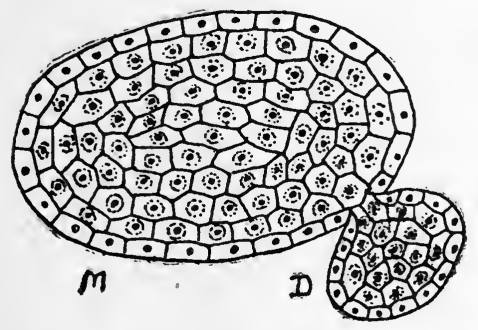

Fig. 3. Reproduction by budding in a manycelled organism, in which the daughter is also many-celled. $M$, Mother; $D$, daughter. The degree of sacrifice is similar to that in Fig. 2. This figure is idealized and might stand for such animals as Hydra and many of the worms, or any of the multicellular plants that produce buds, runners, tubers, and the like. It is a very common method of reproduction. form that it may reproduce again. This allows a more lengthened life, and thus a greater possibility of developing a higher individual.

Fig. 2 represents reproduction by budding in an organism of one cell.

Fig. 3 illustrates a manycelled organism which, in a similar way, buds off a smaller daughter organ- 
ism; but the daughter in this case consists of many cells at the start.

Fig. 4 represents reproduction in a still higher organism, - one made up of many
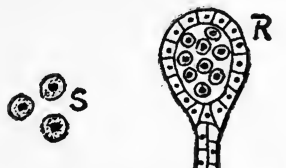

8

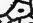

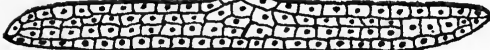

Fig. 4. Reproduction in which a many-celled mother $(P)$ produces many one-celled reproductive bodies or offspring ( $R$ and $S$ ), which are all alike. This may be taken to illustrate any many-celled, spore-bearing plants, such as ferns, mosses, and the like. It will be seen that reproduction, while still meaning division and sacrifice, is much more economical than it was at the beginning. cells, - such as a moss or a fern, or some worms. In this case the difference between the parent(many-celled)and the offspring (one-celled) is still greater than we have had before. It will be clear that reproduction is still division, but is still more economical and less of a sacrifice than it was in the other cases. The parent therefore has a still better chance to go on with its own life history and perfect itself to a degree impossible in Figs. I and 2. Usually such organisms, which have come to economize by reproducing through a single cell, are able to produce many offspring during their life. In this way the species, as well as the individual, profits by the economy.

\section{Further Sacrifices Growing out of Reproduction. -} Reproduction has been shown above to be the first and most fundamental form of sacrifice which we find in nature. It is not merely a sacrifice to produce offspring. This is but a beginning. The care of offspring in order to bring them safely to the point where they can care for themselves is also very common among plants and animals. This is a tax on parents which oftentimes means more sacrifice than 
reproduction itself. As in the case of reproduction there are all degrees of sacrifice from the lower animals up to birds, mammals, and man. In some (as birds) it is merely the storing of a large amount of food in the eggs; in some (as insects) it means the placing of the young in special places where food is abundant; in some (as birds) it means nests and incubation of the eggs; in some (as mammals) it means carrying the young in the body of the mother; in some, particularly in man, it means the building of homes, nourishment, protection, training, education, conscious sympathy and devotion and sacrifice. Reproduction is thus, not merely itself the first, most fundamental form of sacrifice shown in nature, it is the beginning and inspiration of the richest line of sacrifice and unselfish instincts and acts found in men or animals.

Save for reproduction there would be no offspring to care for; yet the connection is closer than this. The very instincts of reproduction are so closely intertwined with those of love and care for offspring that it is impossible to distinguish them. We often find that the mother's love for her offspring is immediate and unthinking and instinctive, - following at once on the fact of reproduction.

6. Summary. - Reproduction is a perfectly natural and normal thing in life. It is next in importance to nutrition. There is nothing in it which should bring shame and aversion. This is not all. While nutrition is individual and selfish, reproduction is unselfish and looks to the future of the race. It is the bridge over which individual selfishness'and energy were first transformed into social unselfishness. It is the avenue by which we are led to the most unselfish acts of which we are capable, - as expressed 
in the devotion of the mother to her child. It is thus the foundation of the most altruistic and spiritual qualities we possess. It is nothing less than sacred. Indeed we have never found any better, more convincing way to picture the relation of God to man than by parental love. Can we afford, then, either to ignore or to abuse the sources of it in the education of our children? 


\section{CHAPTER V}

\section{SEX AND SELFISHNESS}

I. The Introduction of Fertilization. - In Section 4 of Chapter IV a series of illustrations is given to picture some simple steps in reproduction. In Fig. I, which is the simplest, a simple one-celled organism divides into two equal, one-celled offspring. In the last of the series, Fig. 4, we have a many-celled organism reproducing by dividing off a number of single cells. This makes reproduction more easy; but it can readily be seen that it leaves a larger task on the offspring after reproduction. The offspring must grow up from its simple state into a complex form like its parent. The daughter cells in Fig. I have only to increase in size to be like the original parent, and they already possess onehalf the original parent's material to do it with. The offspring in Fig. 4 must do more than grow; it must change in other ways from its simple structure to the complex makeup of the parent.

Quite low down among organisms an interesting device appears, which helps in some way to secure this development. It often happens, among the similar offspring of an organism like that in Fig. 4, that two of the young after swimming around for a while will unite completely into one cell (Fig. 5). After this the large cell formed by the union will grow into an organism like the parent. Just what the gain from this union is we are not sure. Many things have been suggested; and biologists are agreed that 
it must serve some interesting and valuable purpose because it is found all through the plant and animal kingdom alike.

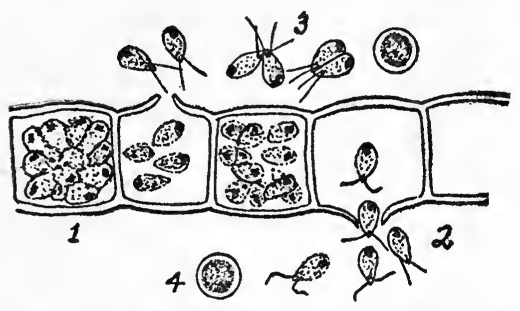

Fig. 5. Reproduction in which a many-celled mother produces numerous, similar, one-celled offspring. These offspring swim about together and finally unite two by two (conjugate) to secure the development of the adult. I, a mother cell producing the reproductive bodies (gametes); 2 , offspring (gametes) escaping; 3, gametes conjugating; 4, the new embryo organism resulting from the union of the gametes and capable of development into the mature plant.

with the power of developing into the adult.
This act of uniting two offspring is called conjugation or fertilization. It is easy to see that it is just the opposite of reproduction, - which is always division. Conjugation is always the union of two organisms into one. The offspring which unite are called gametes. The result of the union is an embryo

2. The Introduction of Sex. - Another advance in this interesting biological series is shown in Fig. 5, where the gametes that are reproduced by the many-celledparent are of two kinds. One class is large and sluggish, and the other is smaller and active. The first are known as eggs (Fig. 6, E); the second, as sperm-cells (Fig. $6, S)$. Usually

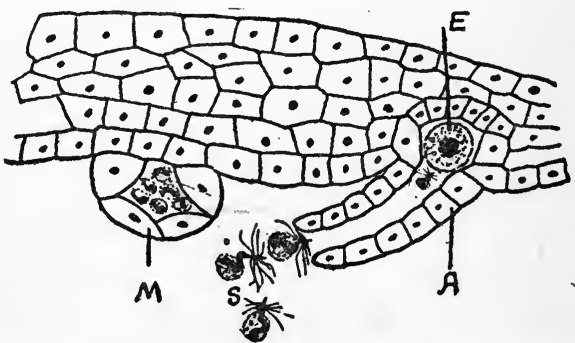

Fig. 6. Reproduction in which the single parent plano has two kinds of offspring; - that is, the parent is both father and mother at once. $E$, the egg, produced in tho special female organ $A ; S$ the sperm, produced in the male organ $M$. The sperm swims down the channel in the female organ and unites with the egg to produce the embryo of the new generation, Here the gametes and the organs that produce them show the male and female qualities, but the parent itself must be regarded as of both sexes. 
an egg and a sperm-cell must unite before any development will take place. Each will die unless united with the other. This union is called fertilization, as in Section I of this chapter and apparently means the same thing here that it did there. The egg is known as a female gamete, and the sperm is known as a male gamete. This difference of the gametes we call sex. This is the first time that the differences of sex have appeared in our series. In Fig. 6 , however, the parent itself is neither male nor female, or if one prefers, it is both male and female. It may produce both kinds of offspring.

Fig. 7 introduces us to the next step in the development of sex among organisms. Hitherto there

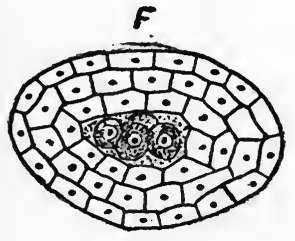

M
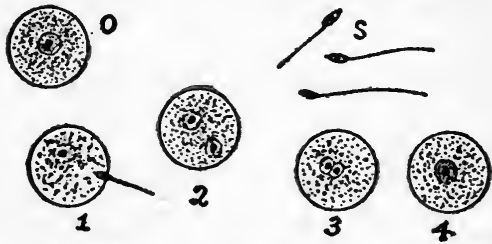

Fig. 7. An idealized figure which may illustrate the condition in any of the higher plants and animals. There are two kinds of multicellular parents, $-F$, the female, producing ova, or the female offspring $(O)$ within, and $M$, the male, producing male offspring or sperm $(S)$. The offspring show sex-differences and the parents no less. $\mathrm{I}-4$ illustrate stages in the union of the gametes, sperm and ova, to produce an embryo.

has been no difference in the parents. Here there are two different kinds of parents. One kind $(F)$ produces only the large gametes or eggs; the other $(M)$ produces only the small, active gametes or sperm. In this case we call the parent which produces eggs a female, and the parent which produces the sperm, a male. This is the condition in all the higher animals, including man. The reproductive cells show very striking sex differences, and the parents of these different kinds of cells are as different as the cells. 
3. The Meaning of the Sexes. - Since we find fertilization, or the bringing together of the one-celled offspring, so universal in nature, we conclude that it is for some reason necessary. In proportion as it is important a new problem arises: How can these two separate sexual cells be brought together with enough certainty and regularity to insure their union and thus insure the new generation? As long as any one of these offspring could go on and make the adult without union, as in Figs. I-4, the problem was a very easy one.

In the first place, in making a success of the new method, it is necessary that more of both kinds of cells be produced by the parents than would be necessary if the cells could settle down and grow at once without union; because in the very nature of the case many of them can never find mates. In the second place, some way must be devised whereby the cells may be brought together, whereby one of them at least may recognize the presence of the other, and may if necessary move so that the two cells may actively unite.

Even in the simplest organisms these conditions are fulfilled. The smaller male cell, of which a great many are usually formed, is active and usually able to swim freely in fluids. It is also sensitive to chemical changes produced by substances secreted by the egg, and is caused by these to seek out the egg, to enter it, and thus unite with it. The egg, is passive except for making this secretion which attracts and guides the sperm in its active pursuit of the egg. This is the meaning of the different qualities of the two sexes in organisms as simple as those figured in Figs. 5 and 6 . Themeaning is practically the samefor such organisms as that in Fig. 7, and clear up to man, where the parents that produce the mating cells are also different. 
The differences between the male and female parents are for the same purpose as the differences between the cells: viz., to bring together with the greatest certainty the male and female cells. The special organs and instincts of males and females exist to insure fertilization. The parents are brought together in order that the cells may be brought together. The bringing together of male and female parents may be known as mating.

4. The Attraction of the Sexes. - The simple conditions described above show why, biologically, the sexes must attract each other. It was seen that this attraction is a purely chemical one between the two cells in the simplest cases. This chemical attraction is found also between these cells in the higher forms; but there is much more than this. As we come up the scale of life to the animals, in whichmaleness and femaleness is found in the parents as well as in the reproductive cells, and the parents have complex nervous and sensitive powers, the attractions of sex become more complex and powerful.

In the main it is still true, as it is with the egg and sperm, that the female attracts the male, and the latter actively seeks out the female. In the higher animals we know that the attraction of the female may be exerted through odor, sound, color, or form. In addition to these attractions through the senses, there are in both parents, but in the male especially, powerful internal instincts and appetites that make them seek one another. These tremendous desires and attractions between the parents, whether conscious or unconscious, have the one biological purpose:they insure the bringing together of the two kinds of cells in order that they may unite and thus make reproduction 
more effective. These mental attractions between the parents lead the way for the chemical attraction of the cells. They secure fertilization and an improved method of reproduction by making mating attractive.

5. The Selfishness of Sex. - It will be clear to the reader that we have in some way come again into a realm of selfishness and gratification. It is quite as much so as that we spoke of in connection with getting food and individual growth. The presence of food arouses the desires of the organism and it responds to it; or the absence of food produces hunger, - an internal desire or appetite of a purely selfish character, - which drives it to seek its food. Just so the presence of the egg or the female may arouse the seeking action of the sperm or male; or internal desires and appetites, looking toward self-gratification, may drive the male to seek the female. We have seen that reproduction is a drain on the parent. It is itself unselfish and accompanied by a beautiful series of sacrifices. It would seem that we have, in following the process of reproduction, fallen again to a plane of extreme selfishness and individual gratification. There is no gratification so keen nor selfishness so deep as the gratification and selfishness of sex-indulgence.

6. Relation Between Reproduction and Sex. - Is there any solution for this seeming paradox? Reproduction is the great biological foundation of unselfishness and sacrifice of the self for the species; fertilization, although just the opposite of reproduction, is for some reason a strong. agency for making reproduction effective by uniting two offspring into one; sex in parents is a very satisfactory means of securing fertilization and of selecting the matings; around sex, and making fertilization still more sure, 
is the most remarkable series of attractions, desires, appetites, passions, and gratifications known in biology. They seem to be as general and practically as powerful as hunger and thirst. We believe this to be an evidence and measure of their importance in life.

The connection seems to be something like this: This powerful set of selfish passions has grown up about the unselfish act of reproduction, and thus helps to insure that the sacrifice shall continue. If it were not for the gratification that attends sex-indulgence, fertilization might fail, and the efficiency of reproduction-even the very sacrifice itself of reproduction-mightcease. The sacrifice is insured by coupling with it a selfish impulse and gratification.

7. These Principles Applied to Human Life. - All that has been described above as belonging to sex life in the higher organisms is equally true of human beings. Consciousness comes in and makes the appetites stronger and more difficult to control; but the fundamental facts are the same. All of this shows that reproduction is as natural and as universal as the taking of food; that some sort of fertilization is almost as prevalent as reproduction; that sex differences are found in well-nigh all animals and plants; and that attractions and appetites and gratifications always accompany sex. The first and most wholesome deduction which we must make from these facts is this: Methods and conditions so universal in nature must be an important part of the plan of God himself, and cannot be vulgar nor vile in themselves. They are as important and as sacred as life itself, since on these foundations all higher life has arisen, held its own, and advanced on its way. 
These broad truths are presented to parents and teachers not so much with the thought that they will furnish material to present directly to the pupils; but rather to give them as teachers a fuller consciousness of the greatness of the place of reproduction and sex in life, and thus form a background for the particular instruction. It will help to lift sex out of the vulgar connections into which it has come through human abuses, if we can realize that it has this wonderful and universal constructive side. It ought, too, to aid us in banishing the embarrassment and false modesty which have so often prevented us from doing our duty in respect to our children.

There is matter in these chapters which should be brought in the teacher's own time and way to the knowledge of the pupils; but the method employed here is that of adults talking to adults, and not to children. 


\section{CHAPTER VI}

\section{SEX IN RELATION TO NORMAL HUMAN PHYSICAL AND MENTAL DEVELOPMENT}

8. Introduction. - We have seen that in animals the task of producing and caring for eggs is the work of the female, just as producing sperm and bringing them where they can unite with the eggs is the work of the male. The nature, structures, and instincts of the female are determined by the task that is hers. In the same way the peculiar organs and passions of the male have arisen in connection with forming sperm cells and with caring for them. In other words, the essential fact of maleness and femaleness consists in the sexual cells. The peculiar features of the male and female parents, which we recognize externally, are purely dependent on the kinds of cells they produce. These features are secondary.

This fact is the explanation of those we shall next undertake to give, and it is important that the reader should recognize the difference between this statement and the ordinary view. We usually think that a female animal produces eggs because she has the normal external characteristics which. we find in the female of that species. In other words, we think of a kind of mysterious principle of maleness or femaleness in an individual, and that by virtue of this principle it develops certain foreordained organs, and these organs naturally produce eggs or sperm. As a matter of fact the essential sex character resides in the sex- 
cells, and the peculiar organs and instincts of the parents are the outcome of these. The character of the body of the parent is determined by the kind of offspring it is developing within it.

2. The Differences Between Male and Female in Humans. - In the early embryonic stages, human males and females are so much alike externally that the sex cannot be prophesied. Later and before birth, however, the fundamental internal differences begin to stamp themselves on the body and the sexes can be distinguished by certain definite qualities and organs. Still later in life, during adolescence, the internal sex organs further influence both males and females so that they come to differ still more.

In man, as in other animals, the fundamental female organ is the ovary (in which the eggs develop); and the fundamental male organ is the testis (in which the cells develop). In connection with this internal difference, and because of it, there arise such well-known differences between males and females as the following: the external sexual organs in the pelvic region; the smaller size and more delicate construction of the female as contrasted with the greater size, muscular strength and activity of the male; the softness and smoothness of the skin in females as compared with the rougher skin and greater tendency to develop hair on the face and body in the male; the broader pelvis of the female; the greater development of the mammary glands; the tendency "to deposit fat beneath the skin especially about the breast and hips.

One other special organ characterizes the female, and is connected with the fact that the human mother, as is true 
of other mammals also, cares for the developing embryo within her own body after fertilization. This organ, known as the uterus or womb, is one of the most wonderful devices found in all biology for the care of the young in the early, helpless stages of its growth. The possession of the uterus and the carrying of the young for so long a period powerfully modifies the activities and habits of the female, and is the biological foundation of a great deal of our human social customs and behavior. See Figs. 9 and ro.

In no less degree are the mental and spiritual differences between men and women recognizable. These also arise not because of some mystical tendency of maleness or femaleness, but from the fundamental differences in the task of producing and caring for the two kinds of sexual cells. It is not intended here to make a careful analysis of these differences. In the female mind there is naturally somewhat more of conservatism, more of reserve, more of emotion, less willingness to take chances; and her disposition is more quiet and less vigorous. In the male, on the contrary, the impulses of sex, of adventure, of combat are more powerful and radical; his mind is, perhaps, somewhat more judicial. There are numerous exceptions, and the primary physical and mental capabilities are the same; yet we all recognize perfectly definite physical and mental qualities which we describe by the words masculine and feminine, virile and effeminate.

It is scarcely necessary to say that to the biologist there is no suggestion of inferiority or superiority in these terms. They merely express the specialization which accompanies sex, - and each type is specialized to do particular necessary tasks. Each is superior in its own specialized powers. 
3. The Relation of Sex to These Bodily and Mental Developments. - One of the most important things for human beings to realize is the vital and profound influence which reproduction and sex have on the whole of the developing personality. In order to make this clear it will again be best to illustrate from some of the higher animals. As is well known, a male horse, or cat, or chicken, if allowed to develop its testes until maturity, is wild, vigorous, active, fiercely combative of other males, easily aroused by the presence of the female, does not readily take on fat, but is muscular and converts its food supply into action. This development involves its whole bodily and mental nature, its disposition and instincts as well as its structures. In the case of the cock, spurs, wattles, and other well-known "secondary" sexual structures appear.

If any such male animals are taken when young, before they show these mental and physical effects of their sex, and the testes are completely removed by a surgical operation, these qualities do not arise. The animal is sluggish, develops fat instead of muscle, is mentally torpid, takes no special notice of the female.

The male fowl, so treated, does not develop the spurs and other male marks. If, however, a piece of the healthy testis of another fowl is later grafted successfully into the tissues of the castrated bird, the development of these ordinary male characters will occur.

Something similar to the above takes place in female animals whose ovaries are removed in early life. There is very little difference physically or temperamentally between males and females when both have lost their essential organs early in life. The developing ovaries and testes are responsible for the special sexual characteristics of the 
parent animal, and the removal of these internal organs makes male and female much alike. It is believed by biologists that the sex-organs, - ovaries and testes, - manufacture certain specific substances, which on being poured into the blood-current pass to the muscles, the brain, the skin, and other organs. These substances, by their presence, stimulate the particular growths that we have noticed as belonging to the various sex-organs. In other words, the natural, healthy condition of the internal sex-organs, through their direct action on the blood, modifies most profoundly the body, mind, and nature of the organism to which they belong.

\section{Relation of Sex to the Normal Development of the} Human Male. - If the facts of the preceding paragraph were true of the higher animals only, they would still be interesting; but since they are just as true of human beings, they become of most far-reaching importance. It is well known that the boy changes in important ways as he becomes sexually mature. The body grows greatly; the muscles become firmer; the vocal cords increase in length, and the voice falls from the pitch of a woman to that of a man; beard develops on the face; the sex-organs increase in size; and the temperament, mental qualities, and ambitions become those of the mature man. If, however, the testes are removed by disease or operation, these changes do not come, but the man keeps the more feminine qualities of boyhood. In this way the voice remains a soprano, the muscles do not become vigorous and manly, fat is deposited in greater amount, the mental traits come to be dominated by stealth and cunning rather than by openness and strength. The eunuchs of the orient are examples of this. 
From the human point of view, the practical conclusion of the whole matter is this:- In order to get a strong, normal, manly body and mind, the first essential is the full, sound development of the internal organs, - the testes. Conversely, anything that interferes with the full, sound development of the internal sex-organs will to that extent prevent the boy from developing into his full manhood. The effect of such knowledge as this upon the average boy in restraining him from lines of action that would interfere with manly development is clear, and the use we should make of these facts in the training of boys is equally apparent.

5. The Relation of Sex to Normal Development in the Human Female. - Without going into details, it will serve the present purpose to say that the same general laws hold for the development of women as are pictured above for men. The loss of the ovaries early in life, by disease or operation, prevents the normal development of the female body, and does not allow the mental and temperamental qualities to come to their proper maturity. As is true for other animals, each sex tends to become more like the other, in the absence of the internal organs. Thus in women, the hips may not enlarge, and the outlines of the body resemble those of men. The presence of healthy ovaries is necessary to produce the distinctive and attractive feminine characteristics.

6. The Abnormal Aspects of Sex in Human Beings. - It has been the effort to suggest in the preceding paragraphs how profound and beneficial is the effect of healthy, normal sex development on bodily and mental development, both in men and women. The long series of attractive qualities 
which each sex admires in the other is dependent upon this healthy sex life. This, as we have said, is the important and positive foundation of sex-education, as it is that on which human society is itself erected. These are the most important and valuable facts of sex. Home, family, love, and the numerous ideas to be associated with these words, rest upon it.

But there is another side that cannot be ignored. This is abnormal, pathological, diseased, and secondary, but it is important, and must be met fairly and squarely by the teachers of boys and girls. It is important, however, that they shall not be allowed to think of the abnormal things as meaning more than the normal. It is not possible in these brief chapters to make a complete statement of the different forms of abnormal sexual life, and of the resultant general life, for which the parent and teacher must be on the lookout. All that can be hoped is to suggest some of the main places where the results of experience should be brought to the aid of young people.

7. Special Abuses of Sex in Men. - We have seen that the removal of the testes makes men abnormal and imperfectly developed in body and mind; but this is not all. Premature and excessive sexual indulgence interferes with sex development and thus with the whole development. Breeders of stock, who wish their males to come to their best, guard this point and do not allow too early or too frequent intercourse or excitement. From the standpoint of bodily and mental health the following things should be held in mind by teachers and impressed on boys:-

(I) Total abstinence from sexual indulgence does not in any way retard or prevent perfect development of the sex qualities. 


\section{(2) Early or excessive or abnormal forms of indulgence} do interfere with normal sex growth and with the strong manly qualities which depend on it.

(3) Promiscuous indulgence is sure, sooner or later, to

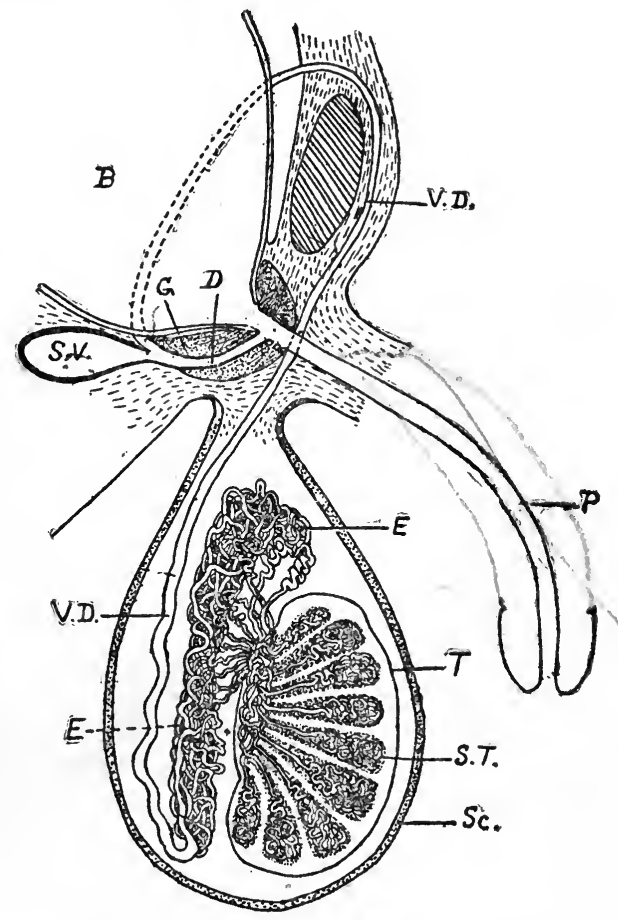

Fig. 8. A diagram of a sectional view of the essential sex organs of the male, seen from the right side. The section is supposed to pass chiefly through the middle plane of the body. $B$, the bladder; $P$, the urethra passing through the penis; $S c$, scrotum containing the testis, $T ; S . T$., sperm tubules where sperm is formed. $E$, epididymis, a much-coiled tube which receives the sperm through tubes from all parts of the testis and conveys it to $V . D$. the vas deferens. This tube leads to a reservoir $(S . V$.$) and finally to the outside world through$ the ejaculatory duct, $D$, and the urethra, $P ; G$, the prostate gland.

Each testis contains about 800 of the much coiled sperm-tubules. These delicate tubes average more than two feet each in length. They unite into about 20 tubes, each some 8 inches in length. All these communicate with the epididymis $(E)$ which has a lengtls of 20 feet when unravelled. The vas deferens takes a circuitous route of some two feet before it comes to its vesicle, $S . V$., just beneath the bladder. The germ infections may penetrate to the most internal parts of this structure, and hence it is easy to see why complete cure is so difficult and uncertain. 
bring infection by one or both of the venereal diseases, gonorrhea and syphilis. These diseases arrest development, and may destroy the whole sex functions. These diseases are not merely communicable from adult to adult, but the germs may penetrate to the ovaries and testes, and the eggs and sperm thus become infected. In this way unspeakable disease and misery are brought to the next generation, as well as to this.

The highly complicated character of the sex glands and the ducts connected with them makes infection of the male by these germs a most insidious and difficult trouble. The accompanying figure (Fig. 8), which is diagrammatic, will give the teacher an idea of this complexity. The whole series of tubes and organs may become diseased.

(4) Naturally, the male has more powerful sex-desires than the female. This is associated with the more active male function of finding and pursuing the female. The selfish appetites and passions are at their highest with him. Because of this fact it is especially easy for the minds of boys to become poisoned and diseased by early and excessive sexual indulgence, or by excitement through conversation, pictures, and the like. This disease of the mind is just as real a thing as the blood-poison of syphilis to the body, and even more deadly to personality.

Because of these more intense passions of boys, and of other facts which bear so directly on their development, the pedagogical problems in rearing boys to pure, healthy maturity are much more taxing than for girls. This makes it all the more necessary that boys and young men be given a chance to know the meaning of the right use of sex and the dangers of its abuse or neglect. 
8. The Abnormal Aspects of Sex in Women.-The impulses towards sex-gratification are less powerful in the female than in the male, and in consequence her abnormalities tend less toward excesses and abuses. There is, however, enough of such tendency to make it necessary for mothers of daughters to see that they are not subjected to unnecessary temptation. If subjected to it, they should see that the girls know the real nature of the temptation, and why it is not be to yielded to.

Since women arouse sexual appetites in men, it is thus possible for them to increase, quite unconsciously, the dangers in which they stand. They should be taught how their dress or conduct may, without their intention, arouse impulses dangerous to themselves and others. It is probably true that no normal woman deliberately seeks to produce these effects; but many girls and women do thus contribute to make the problems of both sexes more difficult.

Since the female carries the developing embryo and nourishes it, her biological work in reproduction involves more of self-sacrifice than does that of the male, and less of gratification. While the woman is not so subject to the impulses and the consequent temptation to excesses, yet the evils arising from abuses of sex seem to fall most heavily upon her nevertheless. The communicable diseases are even more disastrous to women than to men. We are all too familiar with the cruel way in which society holds women more responsible for lack of virtue than it does men. Just how severe is public condemnation and how destructive is overindulgence and disease to women is shown by the social ostracism and the short life of public prostitutes. 
In general, then, the unhealthy and abnormal things in respect to sex from which young girls should be guarded are:-

(I) Forwardness and lack of reserve. This is the danger point with girls as overpowerful sex-desires are with boys; and must be regarded as abnormal and pathological. The very fact that sexual desires are not so strong in women as in men is doubtless the reason why girls often fail to realize that very small indiscretions on their part may lead to disastrous consequences.

(2) Lack of experience; small wages; dance halls and wine rooms. There are many things, in our cities particularly, that make the position of unprotected girls exceedingly difficult: the lack of experience of country girls who go to town to earn a livelihood; the small wages that do not allow for any comforts or relaxations in life; organized vice working to entrap girls through the dance halls and wine rooms. All these things tend to break down the natural restraints and lead girls to unwholesome sex-relations.

(3) Ill-health. - A large part of the sex abnormalities of women are matters of ill-health which cluster about the uterus.

(a) The monthly loss of blood, associated with the period of formation and escape of eggs, is in civilized women abnormally severe, and is the source of much distress and sickness. The debilitating character of the function is shown by the openness to colds and other ills at this time. The proper clothing, rest, and care of the body and mind at this period are absolutely essential to health. School girls, working girls, and society girls need to understand fully that they ignore these cautions at their extreme peril. 


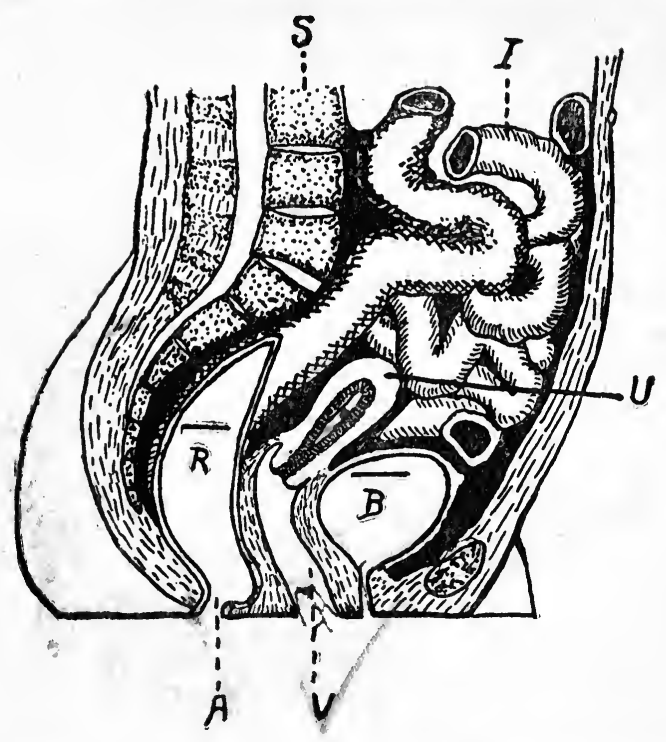

Fig. 9. A diagram of a mid-section through the female pelvic organs, to show the general position of the uterus. It may fall forward, backward, or sidewise. It will easily be seen why the "knee and chest position" (See page 103) is favorable for replacement; also how compressing the waist must force the organ downward. $A$, anal opening; $B$, bladder; $I$, intestine; $R$, rectum; $S$, spinal column; $U$, uterus; $V$, vagina.

(b) In many cases the uterus tends to add to unhealthy bodily and mental states because of its mere weight, particularly at the time of menstruation, and because of its unstable position. The organ is very liable to fall from its natural position (Fig. 9, $U$ ), and may fall in any direction:- backward, which is most frequent; forward; or sidewise. In falling backward, for example, it may bend on itself in such a way that it is impossible for it to return unaided to its original position. In this position it may form adhesions and thus grow to adjacent organs. The bad results of such fallings are numerous. They include 
pain, nervousness, and constipation because of pressure on the rectum, and inability to bear children. When such a condition is suspected because of dragging sensations in that region, painful menses, and the like, a girl should be taken to a reliable physician for examination and advice. Years of imperfect physical and mental life may be avoided by care in this particular.

Figures 9 and ro will give the reader an idea of the general position and nature of these internal organs. A knowledge of their relations and functions is necessary to the teacher in order to make a convincing presentation of the matter to the child.

(4) Unhygienic clothing. - Abnormal feminine dress should be mentioned at this point. There is no doubt that this has improved in recent years; but there is still necessity for sane care. Corsets and other compresses that

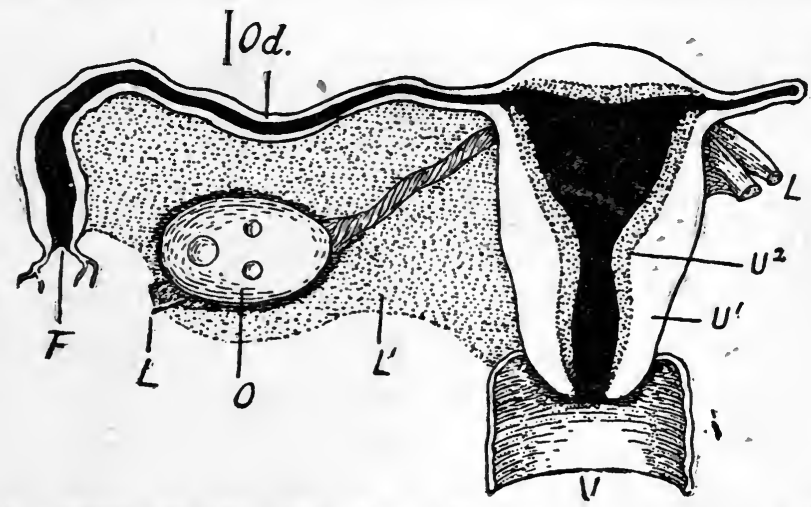

Fig. ro. Section of internal female organs, viewed from the ventral surface. $V$, section of vagina, which communicates with outside world; $U^{2}$, muscular wall of uterus; $U^{2}$, the vascular portion of the wall; $O d$, the oviduct, of which $F$ is the inner opening; $O$, the ovary; $L$, various ligaments supporting the womb. The eggs are formed in the ovary from which they escape into the body cavity; they are taken up by the fimbriated processes at the opening of the oviduct and pass down the latter to the cavity of the uterus. In the oviduct or uterus they may unite with the sperm which ascends from the vagina after copulation. The fertilized egg attaches itself to the vascular wall of the uterus and is nourished there. At birth the child is forced through the neck of the uterus by the muscles of this organ and passes to the outside world through the vagina. 
bind the waist only or chiefly, diminish the space of the organs at the waist line, force them down upon those below, and almost certainly cause the uterus to fall in one direc'tion or another. This result is made still more certain by the flabby abdominal muscles of most women. Abdominal corsets that leave the waist loose and support the abdomen from beneath, are advantageous if the muscles cannot be exercised enough to make them do the work themselves.

9. Summary.- The discriminating teacher or parent will see that the argument in this chapter does not deal directly with the social and moral issues, but only with the biological. On these biological grounds we can go to our children, in the proper way and at the proper times, and say:- "Your development into the manly man or womanly woman that you should become, will depend, in very large degree, on the health and perfection of your sex-nature. This is true both of your mind and body. If your sexdevelopment goes awry, the result will certainly show itself in your general qualities of body and mind. The things that are most likely to produce such a result and keep you from reaching your best are:- too early use of the sex-function, abnormal uses of it, displacement of organs, neglect to care for health at critical times, loss or injury of organs through disease or abuse. Even undue thinking of sex matters, or yielding to the sex impulses, brings a kind of morbid regard for them, and a mental weakness which is not healthy. Total abstinence from sexual indulgence will have no ill effects on the development you are seeking. Therefore total abstinence is wise. The purpose of sex-knowledge is to enable you to let yourself develop normally without giving the matter any unnecessary thought." 


\section{CHAPTER VII}

\section{THE SOCIAL AND MORAL BEARING OF SEX}

\section{Résumé of the Relation of Sex to Mental Life. -}

It does not help us at all in our efforts to fight wrong sex attitudes to shut our eyes to the fact that matters of sex naturally have a large place in the feelings and mental life of all animals, including man. It is equally true that these feelings and mental states and relations, growing out of the contrasts and attractions between the sexes, greatly refine and enrich our whole higher life. Sex fills even a larger place in the life of man than it does in that of the lower animals because, owing to the higher development in his case, of consciousness, memory and reflection, he gives more attention than they do to pleasures and pains. This is illustrated by the care and trouble we take to make our food especially tasteful and attractive. We deliberately increase the pleasures connected with eating by dwelling upon them, and thus make the act of food-taking more agreeable, and consequently we render ourselves more liable to overeating and to the abuse of the function. Just the same thing is true of the sex-life in man. Consciousness and memory greatly strengthen the hold of sex on the mental life of mankind, and at the same time increase the tendency to abuse it and to give it an unduly prominent sway over conduct.

The original purpose of sex instincts is to insure reproduction, and they are strong enough to accomplish this 
in the lower animals. When in man the mind comes to dwell upon the sex gratifications the impulses may easily become unnecessarily strong and lead to abuse and perversion.

2. Sex and Social Life. - Since reproduction and sex lie at the foundation of marriage, home, family, and the like, it is inevitable that they should profoundly color the whole of human society, both as to its ideals and as to its structure. We have seen that sex is a very selfish thing, and that none of the human appetites is more merciless and destructive when allowed to run riot; but we have also seen that it is linked with reproduction, which is the very basis of human self-sacrifice and unselfish devotion. From this deep joining of self and society, appetite and sacrifice, it is inevitable that there must be a struggle to determine which will be supreme and rule the motives, as soon as the mind of man comes to dwell on the conflict. Sex must be deeply imbedded in social affairs. Will sex be allowed to dominate and prey upon social health or will it be forced to take a subordinate place, merely stimulating and ministering to social health?

The foregoing is the theoretical statement of matters; but we all know that it is equally true in practise. We know that the sex bond which brings men and women together as mates, may normally ripen into the richest mental and spiritual companionship and love. We are familiar with the inspiring history of this sound family relationship, extending back in various peoples beyond the very beginnings of recorded history. We know that this ideal bond between a man and a woman makes the home the most favorable place for the appearance, the support, and the 
social and spiritual education of children. Human ingenuity and resource have never found anything that can be successfully substituted for it. It is unnecessary to enlarge on these normal bearings of sex on the social life of mankind. It would be possible to show that all social organization and standards are influenced in the most profound way by sex, and by the special way in which mating problems are met.

3. Abnormal Influences of Sex in Society. - It has been insisted throughout these studies that the normal effects of sex on the individual and on society are those with which we are most concerned. We are not merely trying to keep our children out of pitfalls; we want them to enter into the purest and richest life possible to them. It is, however, necessary to guard against the pitfalls.

It is not possible in a brief survey to give any real notion of the horrible perversions of sex that exist, nor their distinctive and anti-social effects. They are as low and terrible as the purity and fineness of love and home life are high and holy. These things should not be over-emphasized in the education of youth, but it is necessary to make them serve their part in holding youth upright.

The social evils growing out of the abuse and wrong use of sex impulses may be enumerated as follows:-

(I) The breaking up of homes. Unfaithfulness is one of the common causes of the destruction of what might otherwise be normal homes, contributing to the health of society. There is nothing which so strikes down the home and all it stands for.

(2) Prostitution. In every town and city the lust of men creates a demand which results in the ruin of thou- 
sands of women, in the aggregate, and in condemning them to social ostracism, bodily disease, degeneration of mind and morals, and speedy death. These victims are recruited from young girls of every rank in society, who fall usually through ignorance or poverty or love of unworthy men. There is to-day no more terrible blot on our Christian civilization than this sacrifice of women, and the organized machinery by which girls are lured to this certain death. No words are strong enough to condemn the unrestrained men who create the demand nor the inhuman creatures, men and women, who draw women and exploit them in the traffic. Prostitution in all its aspects is revolting to pure minds, and whenever it is portrayed to young people, its cruel and unsocial character should be made so clear that they will never outgrow their first horror of its inhumanity. For this reason, the portrayal should be made to them at that impressionable age when youth is all alive with chivalrous feelings and is expanding into social enthusiasm.

(3) Venereal diseases. These so-called social diseases are extended through society largely through prostitution. They are extremely communicable and insidious, and men and women who lead impure lives sexually are certain to be infected with them sooner or later. It is difficult to get statistics that are reliable, but even conservative physicians have estimated that fully one-eighth of all the disease which afflicts humanity comes from unclean sexual life. The two most dangerous of these sex-diseases are gonorrhea and syphilis.

Gonorrhea is caused by a germ which attacks the mucous membrane of the reproductive passages and may ascend to the very remotest organs, - the ovaries and testes. It may produce entire sterility. Impure husbands thus in- 
fect their wives and may render them invalid and barren. Children born of such mothers are readily infected, and the disease often produces blindness dating from birth. In many institutions for the blind it is known that no less than 50 per cent. of the inmates have lost their sight through gonorrhea. It is uncertain whether this disease is ever completely curable, infection often occurring long after patients have believed themselves cured.

Syphilis, also caused by a germ, is less prevalent than gonorrhea, but is more dangerous in that it may be transmitted in more ways, and is furthermore capable of being inherited. It is not confined to the sex-organs, but becomes a blood disease, reaching the whole system. Because of this it may be communicated through any mucous membrane or any abrasion on the body. Aside from its loathsomeness and infectiousness, the children of syphilitic parents who may have recovered from the disease itself, are liable to be weak and open to bodily and mental diseases. The parents themselves are liable to paralysis and other permanent nervous troubles.

These diseases are more than individual matters; they are social evils. They break up families, they destroy or make innocent wives invalid or barren, they maim and weaken unborn children and put them as a burden on society, and thus in numerous ways strike at the health of the community.

(4) Illegitimacy. Among the distressing social results of unbridled sex-indulgence is the large number of children born out of wedlock. In many instances the mothers of these children are mere girls who cannot possibly have known in full the results of their acts. Such mothers and children are not able to become normal members of 
society. The child has a great handicap and may become the ward of the public, and the mother is rarely given the chance to regain her place in society even if she so desires. It is believed by many students of the question that births out of wedlock are on the increase. Whether this is true or not, illegitimacy is so common that it is a social threat, and it is time that all who care for the future of the children of the land should use every effort to check it.

4. The Moral Bearings of Sex.-From what has been said in the former paragraphs, one must feel that such individual and social disasters necessarily make this matter of sex behavior one of the most crying moral questions of human society. Who will doubt for a moment that ideals of a pure home and regular marriage bond, the rearing of healthy children as offerings to a sound society, the devotion of the whole family in sacrifice for the betterment of human conditions are high moral enterprises? Who will not say that high morality belongs to the young man who in spite of all temptations keeps himself as pure as he wants his wife to be? Or who will not brand alike the prosperous man who lures, for his own lust, the poorly paid work girl by the glitter of the comforts he can give her, and the prosperous man who pays the work girl so poorly that she falls an easy victim to such lures? Most immoral of all is the unspeakable "cadet" who earns his livelihood by winning the affections and ruining the lives of unprotected girls in order to turn them over to a life of prostitution by the proceeds of which he is supported.

There is no realm of social morals in which good and bad, high and low, are so possible as in the sex relations. 
5. Human Standards to Protect Social Morals. - It is very clear that young and inexperienced people cannot always find within themselves the necessary strength and knowledge to guide properly their sex-behavior amidst the complex temptations that society has thrown around them. Not all young people have normal home life. It is for this reason that protecting standards and conventions are valuable, and that all teachers should uphold such standards and conventions. The institution of monogamy, and its safeguarding by legal sanctions,- as compared with polygamy or other experiments which the race has tried,- has done more than anything else to build up sure foundations for society and social morals. All efforts to break it down should be resisted to the utmost; and our children should be trained to regard it as sacred. In the same way the standards that respect and insist on purity in the home are of vital importance and should be equally binding on both sexes. The salvation of society has been the increasingly high standard held up for women. If society would rigidly apply the same standard to men it would greatly strengthen the morality of sex-behavior. When we appeal for one standard of sex morality for men and women we mean the standard we have for women. It is not too high; that demanded of men is too low.

6. The Inner Personal Morals. - It is quite possible that some parent or teacher may ask: "If it is true that sex is normal and sex-desires are implanted in order that reproduction may occur, how can it be said that sex-indulgence can have anything immoral in it, - any more than eating or any other natural act?" This is a natural and legitimate question. 
If we were not different from the animals, no wrong would attach to sex-indulgence. If the door is thrown open it must be opened to all. This would mean promiscuous intercourse without restraint. The social effect of this would be to destroy confidence in virtue and even ideals of virtue, to leave no place for the home and the emotions that belong to it, to make impossible the effective care of children, and to destroy completely the conception. and sentiments of fatherhood. In a word it would thwart, so far as humans are concerned, all effective mating and care of offspring, and break up the most basal unit of human society, - the family.

We have then in human society this dilemma:- Shall we indulge the sensuous gratifications of sex as animals do? Or shall we exercise self-control in the interest of the higher social values? It is always at this point that personal morals appear. As soon as it is clear that - the choice lies between individual self-indulgence and self-restraint in the interest of a higher and more general good, the issue becomes a moral one. This is true even if the proposed act itself be otherwise natural and harmless.

It did not take the voice of God, saying, "Thou shalt not commit adultery" to make irregular intercourse wrong. Neither do our laws nor our public opinion and social standards make it immoral. Its immorality is much deeper than these, and these prohibitions have come out of that deeper thing. That thing is, that all human society and its fineness and inspirations and sacrifices are automatically destroyed by self-indulgence when the individual refuses to restrain this impulse in accordance with these social standards. Sex-indulgence is not merely a blow at the present 
form of society; it strikes at the foundation of all society based on home and family.

7. Incentives Leading to Self-Control. - With a tremendous selfish impulse such as the sex-appetite, self-control means what the psychologist calls an inhibition. An inhibition means back-fires to check the impulse; it means bigger impulses to overwhelm the evil one; it means a "will to do without, overcoming the desire to do."

Now there are various incentives which may serve as inhibitions to the boy or girl coming up to face this question of personal behavior. Some of these are named below, and each should be used at the time and in the way which will bring the best result in immediate conduct and in permanent character:
(I) "Thou shalt not" of human or Divine command.
(2) Fear of injury and arrest of development.
(3) Fear of disease.
(4) Respect for public opinion.
(5) Disgust at the grosser phases of sex abuses.
(6) Respect and consideration for other personality, passing in the case of boys into a chivalrous attitude toward women.

(7) Positive personal standards of judgment, ideals of conduct, and habits of action.

These are stated somewhat in the order in which they appeal to youth, beginning with the lowest. The first three are negative appeals, and are to be used sparingly in early life, and at critical points, and held permanently over those whose moral growth does not advance them to the point where the higher motives appeal. Disgust is a somewhat more personal and lofty quality than fear, 
and can often be inspired before a child can give all the grounds for its feelings. This feeling arises from the fundamental instincts of right and fairness, which many children possess in a degree much beyond their powers of reasoning:- "For of such is the Kingdom of Heaven!"

Respect for public opinion and public conventions is somewhat higher and more complex and is very important. It should be worked into the nature of the child's thoughts of sex until it forms a kind of permanent background to its consciousness, so that the child can do no act without asking himself how this act will affect the feelings of those who love him best. The known demand of a family or community for chastity and purity is a great stimulus to right action in young people. Lax public ideas of modesty and restraint are a prelude to the breaking over of stronger barriers by the young. United demands on the part of young women of a community and their parents for clean lives in the young men will be to them one of the strongest possible inhibitions of loose living.

A greater help still to a young man in enabling him to fight his worst impulses, is to have been trained in such real respect for the personality of a woman that he would realize how she would be wronged by his act, and in such consideration for women in general, that it would become a chivalrous desire to protect them from himself as well as from others. In this connection it ought to be recognized that pure love for a young woman is to most young men a clear call to chivalry; and ought to be used to appeal to self-control. It is a remarkable evidence of Divine wisdom that the same period of development in life that brings lust brings also chivalry, its most effective antidote. 
In practice, any one of these incentives which will effectively do the work of checking the impulses to self-indulgence is as good as any other for the moment; but in personality it makes a world of difference. Our objective in education is to secure the internal standards of right thinking and acting which will safely inhibit wrong action,- - using all the others as aids whenever necessary. This is the highest of all. "Only nobler impulses and good ideals can inhibit the lusts of the flesh." Therefore, as teachers, we must secure these with our teaching.

8. Sex and Religion. - It is well known to students of childhood that the nature undergoes profound changes during the period in which the sexual powers mature. This is not an accident. It is the result of the developing sex qualities. During this period the child is highly impressionable both by good and by bad. Love opens the way for the highest and the lowest. If the animal impulse tempts to abuse and indulgence, there are other instincts, equally associated with the maturing nature, that lead to purity and to spiritual control. It has been shown by statistics that this is the general period of youth in which religion makes its strongest appeal. In early and again in later adolescence, more than at any other age, young people take their stand for religious life, and can be aroused to enthusiastic philanthropic work, which should always accompany religious profession. It is not an accident that love of God and love for mankind and the maturing of the reproductive impulses come together. They are all part of the fundamentalunselfishness of the reproductive process. It is the privilege and duty of teachers to bind them together for the improvement of all. 
9. Summary. - The teacher who aspires to assist the child in sound sex-development must keep in mind the general path over which the wonderful impulse has come and the contributions it has made to personality, in literally molding the physical nature; giving peculiar quality to the mental life and to disposition and temperament; laying the foundations for social instincts and conduct in mating, home-making, care of children, and the like; furnishing one of the most remarkable and trying arenas in which every life must fight out moral battles to determine whether self-indulgence or the higher things shall rule the life; even heightening the sensitiveness of the early life to the call of God in the individual soul. The teacher must remember also that at every step this great constructive factor threatens to take control of the nature, and to break down and destroy all that has been so laboriously built up.

This is not what is to be taught the children; it is the kind of thing the parent and teacher must feel while they bring to the child the graded facts of his life and relations. And yet the youth should somehow get the sense of these big agencies which he may invoke in helping to make his knowledge practical, in forming ideals, and in establishing habits of action. 


\section{CHAPTER VIII}

\section{TIME AND MANNER OF INSTRUCTION}

1. Introductory. - Up to the present we have been making a statement of the problems confronting conscientious parents and teachers, and have tried to give the subject the bigness and dignity to which it is entitled because of its biological importance and its pedagogical and moral possibilities. An effort has been made to furnish the point of view the teachers should have in their approach to the actual work of mastering the problem and of instructing and inspiring youth, rather than to suggest just the information which the pupil must have at the various stages of his development. This book is an effort to supply the first of the pedagogical needs mentioned in Chapter III, Section 2, - the "Motivation of the Teacher."

2. The Matter of Instruction. - It is undoubtedly true that the educational world is now awakening to the duty that rests upon it, and that the indifference and hostility of parents toward this more thorough instruction are gradvally passing away. Our next need is to know what is to be taught, and when, and by whom. These are more difficult pedagogical problems, and it is not pretended that they are completely or even reasonably worked out in what follows. What is put down here is merely tentative and suggestive. It is believed, however, that the general principles followed in the analysis are sound, and that 
some of the special suggestions will prove essentially correct. It is fully expected that we shall, with fuller facts derived from experience, be compelled to modify it radically, at many points. The suggestions as to age will be found to be made broad and elastic, purposely. There will be many individual exceptions to even the best of these suggestions. Indeed the chief objection to proposing a scheme like this is that parents or teachers may take it as final, suspend the use of their own insight and common sense, and in consequence make a failure of the whole effort in cases they may be working with. Education, in a complex realm like this, is as varied and uncertain a task as that in any moral matter that strikes down to the very center of personality. It is not capable of being put in any simple formula which will meet all the cases; but must be made the subject of continuous study and readjustment by the parent or teacher who wishes to secure high character in children.

3. The Periods of the Child's Life as They Relate to Sex-Instruction. - The division of the life of the child for the purpose of grading properly the instruction in sex depends on several things: first, and chiefly, on the progress of his own development intellectually and sexually; second, on the transitions in his social life - from home to school, to high school, and the like; third, on the age, sex, and character of his companions; fourth, on his reading; and on other similar considerations.

For the purposes of this chapter the following general divisions will be used:-

A. The Early Stage.

(I) From birth to 4 or 5 years.

(2) From 4 to 6 or 7 years. 
B. The Early Adolescent Stage.

(I) Prepubertal Stage: from 7 to ro or II.

(2) Pubertal Stage: from Io or I I to I4 or I5.

C. Late, Adolescent or Post-pubertal Stage: from 15 to 18 or 20.

It is not intended to make the time limits of the terms used above accord exactly with their meaning in standard works on adolescence. The terms are applied to describe the most dominant facts of the periods.

4. The Early Stage: from birth to 4 or 5 years. -

(a). The teacher: Without any doubt this should be the mother.

(b) Spirit and purpose for the period: All that can be done is merely anticipatory, protective, and formative of good habits.

(c) Contents and matter: Cleanliness and care of parts; regular and prompt attending to the bodily functions; habits of keeping hands and attention off the organs; no differentiation of sex matters from other matters; use of proper scientific names, and not vulgar nicknames for the pelvic organs and processes.

(d) Remarks: Any unnecessary sense of shame or embarrassment about such matters should be avoided. This does not mean that the child is to be encouraged to talk freely of these things to strangers. They are family matters, to be treated freely among the family, but not mentioned to strangers, because they are private affairs.

The child should preferably sleep alone, should rise promptly on awaking, should not be dressed too warmly nor with tight-fitting garments nor in such a way as to 
favor putting the hands in the region of the organs, and should have plenty of active play.

5. The Early Stage: from 4 to 6 or 7 years. -

(a) The teacher: The mother, possibly supplemented by kindergarten or primary teacher.

(b) The spirit and purpose: A frank meeting of the natural questions of the curious child in such a way as to avoid a sense of shame or a cessation of confidence in his teachers; to arouse a sense of reverent wonder at the mysteries of life, and a feeling of the sacredness of the body.

(c) Contents and matter: Continuation of everything begun in the former period; also the general facts of reproduction in the animals best known to the child, - as chickens, mammal pets, man; where the baby animals and baby human beings come from.

(d) Remarks as to manner, etc.: The questions of the child should be answered frankly, meeting the intellectual needs of the child just so far as they are felt; the information about reproduction should not be abstract generalizations, but should be related to the child - as his chickens, his kittens, babies of his own acquaintance. Broad generalizations are not usually necessary. If this period is properly dealt with, much of the vicious information may be anticipated and rendered less harmful. A sense of partnership with his parents in this knowledge is valuable. The average child learns more during these years than at any other period of equal length in his life. Much will be gained if the sex facts can take their place normally and without shock in this growing knowledge.

6. The Prepubertal Stage: from 7 to 10 or 11 . -

(a) The teachers: Parents and all the teachers. The 
parent is still in the best position to do the work, if possessed of the necessary knowledge; but all possible agencies need to be used during this and the next period, - often unobtrusively.

(b) Spirit and purpose: To secure good habits, as in preceding periods; watchfulness, on the part of all, that the child be kept well nourished and be well supplied with physical exercise in which he is interested, - be kept busy and the surplus physical energy be used up. Keep vacant time full of good books, good play and good companions. Ideals of strong, healthy bodies should be formed.

(c) Contents and matter: Somewhat as in former period, but may be extended. The direct sex-teaching is at its minimum in this stage. Most of the teaching should be indirect and connected with health of body, with nature study, plant breeding, and other similar topics that come up in school. In the case of especially precocious children some of the precautionary teaching of the next stage may be given.

(d) Remarks as to manner, etc.: Children of this age, who have been taught properly will have had their curiosity satisfied with respect to the first mysteries that have raised questions in their minds. If this has been done properly and not evasively; it will tend to keep their minds off matters of sex. They are not yet stirred up by their own sex-development, and normally at this age they are little concerned with its questions. Boys are interested chiefly in playing with other boys. They want to be big men. They are not usually much attracted to the girls. The manner of approaching them should be through these physical ambitions. Boys of this age should be taught of the fine bodily and mental traits of strong men; and 
girls of the normal and vitally attractive traits of womanhood. All of this should be quite indirect and incidental, letting them discover, and imitate such things under the spur of their own ambitions and admirations. A series of measurements of a boy's chest, and thigh, and biceps during these years, with suggestions that he is above normal here or not up to standard there, and how to remedy such matters, will lay the foundations of pride in his own bodily future that may keep him from various dissipations later. The relation of normal sex-development to normal manly strength and vigor may be suggested. Though the boy does not yet know what is coming to him in development, the teacher does; and every incidental opportunity in any subject of study or conversation should be used quietly to appeal to the manly, self-respecting and other-respecting qualities which will serve as inhibitions later.

7. The Pubertal Stage: from 10 or 11 to 14 or $15 .-$

(a) Teachers: For the girls: the mother, or some close woman teacher (school or Sunday-school). For the boys: the father or mature personal friend, teacher, athletic director, etc.

Teachers at this age need to be very intimate and close personally, and capable of giving exact and reliable information without arousing embarrassment or antagonism, and without over-emphasis.

(b) Purpose and spirit: To secure mental preparation for the sexual changes that come to the body, mind, and morals; to guard against the temptations to dwell on licentious mental pictures' and ideas, or to indulge in experiments with the organs and in secret self-abuse; to sublimate and spiritualize the tremendous impulses of sex, and to trans- 
form them into sound ideals and habits of self-controlled sex-conduct.

(c) Content and matter: The elementary facts of reproduction and sex in organisms, and the changes that come in human beings at puberty; the facts concerning seminal emissions, menstruation, "etc., - their naturalness, their meaning, and the methods of self-care that are necessary to prevent unnaturalness and harm from them; the bodily value of sex health in later life; the mental and passional characteristics of this period quite as much as those of the body; the meaning of the changes in temperament and of the sex longings and appetites; definite warnings with sound reasons (but not overstressed) against masturbation; the physiological connection of all these conditions and changes with genuine, fine manhood and womanhood; examples of chivalrous attitude of men toward women and the meaning of it (preparatory to the next stage where this sense of chivalry must function to strengthen self-restraint in young men); formation of purity ideals and standards in relation to girls, and the reasons why these standards are sound for human beings; nature-study, biology, physiology, and religion. Among girls ideals of modesty in behavior, need of avoidance of loudness and forwardness, and the beauty of chastity should be made as appealing as possible.

(d) Remarks as to manner, etc.: A division of labor is called for in this period. Some of the above instruction can best come from the parent or close friend. Other parts of it can be given better in the schoolroom, in the Sunday-school class, in the gymnasium talk, or elsewhere. Sometimes, possibly, it is direct teaching, sometimes it ought to be very incidental to the general teaching. A little examination of 
the above list of topics, in the light of this suggestion, will readily reveal the general division of the work that will usually meet the needs best. The school courses in naturestudy, physiology and biology ought to furnish the big foundation in information and the general background. These teachings are authoritative, and in large degree impersonal. For this reason they strengthen greatly the more individual work of the parents and personal advisers. This is a tremendously important age, and the sex yearnings are not to be ignored or suppressed, but are to be organized and directed so that their energy may be used to drive the child into sound attitudes and courses of activity. One or two talks by physicians to boys and girls, separately, may be very valuable, especially if there is no other formal teaching.

8. Post-pubertal or Late Adolescent Stage: from 15 to 18 or 20 . -

(a) Teachers: High school and college teachers, parents and ministers if well informed, physicians, athletic directors, and books.

(b) Attitude and purpose: To fill the life with high purposes, ideals, and ambitions which will absorb the thoughts, strength and purposes; to give the beginning, at least, of personal vision as to how these ambitions are to be carried out and a conception of the personal qualities which alone will bring full success; to develop further the finer sense of respect for self and for others which will tend to inhibit low actions; to enlarge the sense of chivalry in boys, and admiration for chastity in girls; to stimulate interest in life, its possibilities, its work, its opportunities; to make very clear the effects on all con- 
cerned of improper sex-relations; to convince of the futility of the weakling in the struggle for any sort of success that counts; to utilize the love motive, which is large in most youths of this age, in order to inhibit improper sex-conduct; to form and to appeal to religious ideals and motives for the same purpose.

(c) Content and matter: Meaning of love, marriage, and the home, and the progress made in human history in the purification of it; the racial value of this as compared with general indulgence; the facts of prostitution and of the venereal diseases as they bear on health and personality; the value of purity as a personal asset to the individual; the obligation of purity assumed by young men and young women alike in marriage; the iniquity of the "double standard," and the rôle of young women in insisting that men shall have the same standard of sex-conduct which women practise; eugenics, and its biological foundations.

(d) Remarks as to manner, etc.: This is the first period in which, in anything like normal conditions, there is much danger of young men indulging in illicit sexual intercourse. A wholesome fear to propose such a thing will ordinarily deter them from soliciting this in the earlier years. The danger, however, lies chiefly in an ignorant forwardness on the part of otherwise normal girls which will destroy this natural fear on the part of companions of their own age, and may also subject them to the advances of older men.

The manner of imparting the information and ideals suggested above should be such as to leave no possible ground for a girl exposing herself to danger by breaking the bounds of ladylike conduct; and should make it exceedingly difficult for a young man to take advantage of such a lapse. After all is said, assuming that information respecting 
sex and sex-relations is wholesome and accurate, the writer believes that high standards of modesty and womanly virtue in girls, and chivalrous respect for such in women on the part of young men, will do more to bring selfcontrol to men than fear of disease or any of the abnormal outgrowths of sex-indulgence. My own observation is that a chivalrous wish to protect women and to keep them pure, together with the feeling of obligation to be just as pure as he wishes his sister or his wife to be, will do more than any other thing to tide a young man safely over this period of life.

If this can be coupled with, and intensified by, strong personal moral and religious convictions, it is the crowning of a very strong line of teaching.

9. Summary. - A little attention to the foregoing suggestions will reveal the fact that the course of instruction is progressive toward higher and higher types of knowledge, and the motives to which appeal is made are of a more and more lofty sort. It should be remembered by teachers that it is often possible to use in small degree qualities and motives before the period in which they function most fully. For example, the religious motive seems to reach its climax in late adolescence, but it may be used in some degree before this time. It is important, however, that we should not prematurely stress these higher motives in our treatment of the child. This is often disastrous, both to the quality of the religion (or other influence) and to its effects in furnishing sex-control. The point to be kept in mind at every step is that the instruction should be graded as completely as possible to the child's mental capabilities, to his emotional development, and to his sex needs, - both individual and social. 


\section{CHAPTER IX}

\section{EUGENICS}

1. Introduction. - There is an increasing disposition for careful students of human affairs to hold that children have a right to be well born; to insist that society should take steps to see that those who bring children into the world are fit to do so. It is held that human beings, by applying the same principles which are now in common use in breeding and selecting the best plants and animals, could improve the stock of the human race, physically, mentally, and morally, as much as wheat and horses have been improved. This science which looks to the improvement of the human race by breeding is known as Eugenics. It proposes a better race of man through selective mating, and is supplementary to, and in contrast with, Euthenics, which refers to making the most of the life of the individual, by giving it the best possible chance after birth. Eugenics has to do with "blood" rather than with culture.

2. The Essential Contention of the Eugenist. - On analyzing the above program, we find that the problem presents itself to the student of eugenics in about the following way:

"Our humanity and our moral standards will not allow us, when a child has once been brought into the world, to subject the unfit to the rigors of competition which in the lower animals eliminate the weaklings and keep up the 
average of the stock. Instead, in theory at least, we take even these defectives and apply our resources to give them as nearly a normal individual life as is possible. In doing this, we subject the race to the handicap of propagating and supporting an unnatural number of defective strains. By artificial protection, we are pouring back into the stream of human life the unsound elements which nature eliminates in other species. We believe that the moral and altruistic qualities we cultivate in saving the weak more than compensate for the other loss. When, however, this individual right to life is admitted (and consequently our obligation to enrich this life), it should not carry with it the right to reproduce. Reproduction is not an individual right. It is primarily a social phenomenon. Human society in the interest of its own advancement and soundness has the right to deny the privilege of propagation to those who are for any reason unfit to reproduce.

"In, the second place, in order to get the best results in offspring, there are certain principles of selective mating which should be respected. Individuals, who under proper conditions might marry and produce sound offspring with one mate, may not do so with another. We now know enough of heredity to be able to say that some individuals should not be allowed to reproduce at all. We are gradually gaining the kind of information that will enable us to say that certain particular matings should not take place and thus give some guidance in selective mating, in order to get the very best results for the race."

It is estimated that about one per cent. of the total population of these United States is cared for by society in institutions - as insane, feeble-minded, epileptic, blind, 
deaf, criminal, and paupers - at a cost of one hundred million dollars per year; and that six to eight per cent. of the mature population is so unproductive and inefficient as to be a standing menace. The knowledge that many of these characteristics, or the qualities of mind that made the conditions, are inheritable, is the basis for the plea that enlightened society should prevent unfit marriage and propagation.

3. The Things That Influence Birth. - The above contention may be somewhat new to our ears; but it is certain to be brought more and more to the attention of society in the years to come, because we are learning as never before the facts about the inheritance of human traits. These illuminating studies of heredity, which have been made in the last twenty years, make it necessary for us to consider briefly the elements that help to determine how a child may be "well born," - or whether prospective parents are fit to propagate their kind. Broadly speaking there are three elements or aspects of parental fitness or unfitness to add to the population: (I) physical and mental and moral disqualifications, which are certainly transmissible to children through heredity; (2) qualities, such as infection by the venereal and other diseases, which while not strictly heritable are yet capable of being transmitted to offspring at or before birth; and (3) inability, personal or economic, to give children a chance to enter into the world's activities with a reasonable hope of normal success. Classes I and 2 fall properly in the realm of eugenics. Class 3 includes some phases of euthenics, but in all probability it will be found that much of this inability is a matter of hereditary structure belonging to $\mathrm{I}$, and not purely of social conditions. 
4. Hereditary Transmission of Taints. - There is much about heredity of which we are still ignorant. Our experimental knowledge of just what may or may not be inherited, and of the chances for its actual inheritance is mostly the result of the work of the present generation of scientists. Our knowledge is as yet very incomplete; but we know that inheritance extends to mental, temperamental, and moral qualities just as certainly as to physical. We know that epilepsy, feeble-mindedness, idiocy, insanity, shiftlessness, criminal tendencies - including those toward sexual indulgence - selfishness, laziness, and other similar weaknesses of mind and morals are subject to inheritance. Similarly we know by careful study of statistics that poor resistance to tuberculosis, weak heart, poor qualities of blood and of the internal secretions, and many other weaknesses which serve as the foundation of diseases, are clearly transmissible. The children of inebriates are very liable to nervous weaknesses, epilepsy, imbecility, etc. On the other hand it is fully demonstrated that traits of strength as well as taints are secured through heredity. General bodily strength, resistance to diseases, mechanical ability, memory, cheerfulness, musical and artistic and literary ability, and strong moral qualities, such as unselfishness, conscientiousness, etc., are capable of direct transmission.

Students of eugenics are able to tell with some exactness the probability of the inheritance of both the strong and the weak qualities, if the condition of the parents in respect to these qualities is known for one or two preceding generations. The principles underlying these conclusions are too complex for statement here, but an illustration may be used. The following statements relate to imbecility, but they 
apply broadly to any of the traits that are subject to inheritance, both good and bad.

(x) If both parents are normal and come from normal parents all the offspring will be normal, so far as inheritance is concerned.

(2) If both parents are mentally lacking and come from parents of the same kind, all the offspring will be defective.

(3) Between these two extremes will be all sorts of possibilities too complex to discuss at length here. For example, two affected parents may have 50 per cent. or all normal children, depending on the grandparents; twonormal parents, if they belong to strains having the same defects, may have approximately 25 per cent. abnormal children; if one of the parents be normal and of strong ancestry, all the children may be normal, though some of these may have defective children under certain circumstances; or a normal person, with a defect in his ancestry and with a feeble-minded mate, may have 50 per cent. of his children defective.

It will be seen that both the individuals concerned and their families must be considered; for no individual shows in his own body all the qualities which his germ cells may possess. Only a study of several generations will determine the latter.

5. Congenital Infections. - It is known that syphilis and gonorrhea, if not inherited, - at least infect at or before birth a very large percentage of the children of infected parents. In this way thousands of children are born blind, diseased, or so arrested or disordered in nervous development that they may be epileptic, imbecile, or insane.

In a manner that is similar but not hereditary, parents 
with tuberculosis and some other diseases of skin and mucous membranes, may infect their children at or after birth. This may give them little or no chance in life and render them a burden to society, as well as centers of infection for later generations. This is in addition to the known inheritance of weak organs that may predispose to the diseases.

6. Social or Economic Incapacity. - This is a very complex thing and we do not yet know what elements enter into it in any case. Undoubtedly there are often elements of physical, mental, or moral weakness not yet identified, which are inheritable. But apart from these transmissible weaknesses, it not infrequently happens that persons able to produce perfectly healthy, normal children find themselves beset by such economic conditions that they could not properly care for them. Such persons should not evade their debt to society; still, many things besides hereditary qualities are necessary before such children can become helpful members of society. It would seem, therefore, that society has a duty here in furnishing such conditions that sound children shall have a fair chance to come to efficient maturity. This is a point where eugenics and euthenics must meet in the effort to solve a difficult problem.

7. Relation of These Considerations to Human Marriage. - Growing out of these discoveries concerning heredity during the last twenty years are several conclusions for the improvement of the human race:-

(r) Human reproduction is a social and not an individual matter; hence human marriageshould beguided, in large part at least, by scientific facts and in the interests of society.

(2) Unfit individuals, who have themselves inherited 
taints such as those mentioned in Section 3 of this chapter should not be allowed to marry unless it can be shown by scientific investigation that their marriage is not likely to result in tainted offspring. If there is a probability that it will, these defectives should either be segregated during the reproductive period or bemadesterile by the removal of the glands.

(3) Society should require male applicants for marriage licenses to produce a certificate of complete freedom from all venereal diseases, signed by a competent and reputable physician. In the meantime, parents should demand this freedom from disease on the part of the young men who would marry their daughters.

(4) Young people should be trained in a thoughtful attitude toward the qualities of their mates and of the families to which they belong. They should be allowed the widest possible acquaintance with different kinds of suitable people in order that the range of their selection may be as wide and sane as possible. There is no desire to replace love and congeniality with stern, emotionless scientific selection even if we could know absolutely the results of unions; but there is no question that some knowledge of eugenics on the part of young people would tend to diminish the haphazard marriages of the present day, and give to the selection of mates at least a flavor of intelligence.

\section{Other Reforms Made Necessary by These Facts. -} It is not enough to prevent marriage and reproduction on the part of defective and habitually criminal individuals. It is incumbent on society, and our young people should be educated so as to understand that it is their duty, to handle in a sane and scientific way the physical and moral plagues that cluster about sexual immorality. The 
venereal diseases, which are strongly communicable, are much more harmful and dangerous to the human race than small-pox or scarlet fever. Strict measures should be adopted requiring physicians to report such cases to the health officers, who should isolate them, whether prostitutes or men of loose morals, just as in other infectious and communicable diseases. All this is demanded purely on hygienic grounds and has no direct reference to moral necessities, although these latter may properly reinforce the former.

Prostitution, the white slave traffic, and their horrible accompaniments of immorality and disease, must be dealt with just as vigorously and scientifically; so must, for that matter, the social and economic conditions that minister to these things by making it difficult for girls to support themselves honestly in our cities. Thus the ideals of the advanced scientist and the dreams of the reformer point in the same direction:- to the elimination of the individual transmission of hereditary taints wherever possible, to the elimination of the great centers and avenues of dissemination of the communicable and transmissible diseases; and to the elimination of economic conditions of life that make purity unnecessarily difficult. All this is for the double purpose of removing from the human stock physical and mental degeneracy due to birth, and of checking the moral disintegration of our young men and women through unnecessary and unnatural temptation.

While the scientists are working out the facts on which eugenic progress depends, we as teachers and parents should be educating a generation of men and women who will appreciate them and will do their part in applying them to human betterment. 

\begin{tabular}{|l} 
APPENDIX \\
APP
\end{tabular}

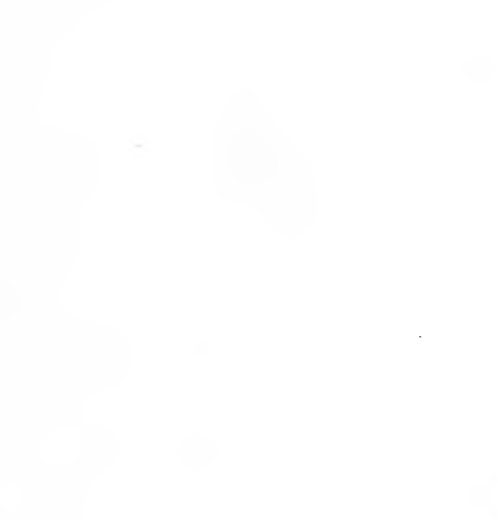

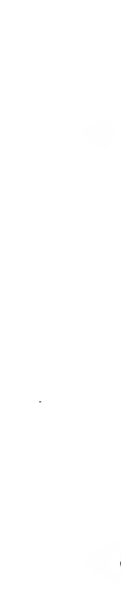

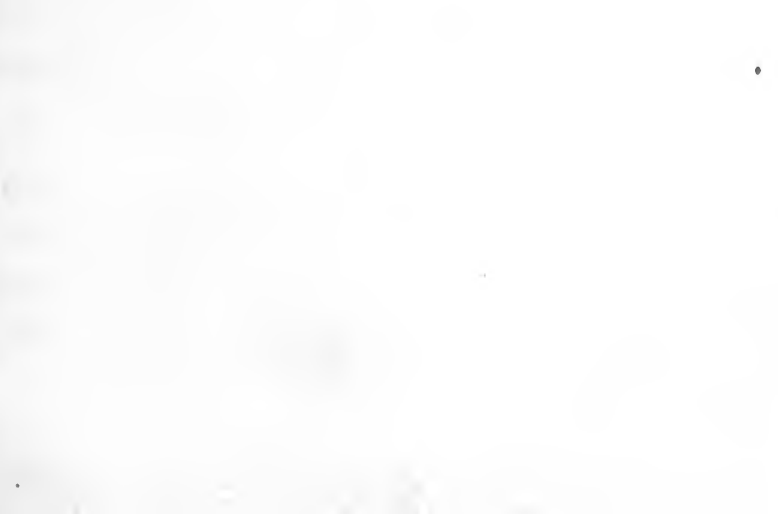




\section{APPENDIX}

\section{THE PROBLEMS OF PARENTS*}

It often happens that parents or other teachers, who are quite willing to admit the need of adult help to youth in matters of sex, do not see a way to meet the particular problems that confront them in practical dealing with children. To such it may be said that there are not a great many of these critical problems. Furthermore they are much more easy to meet than they seem on the surface. The young child is open-minded and quite innocently desirous to know; it has none of the embarrassment which older people have allowed themselves to acquire; we only need therefore to be quite natural and sympathetic in order to get a sympathetic hearing from the young child. The parent should meet each situation that arises in such a way that the child will feel that he may go to the parent freely when he desires to know anything about this or related subjects.

The sole purpose of this appendix is to deal somewhat concretely with certain of the more common problems which parents should help their children meet. These questions, especially the early ones, will usually come out of a clear sky. It is the part of wisdom therefore for the parent to be prepared beforehand. Hence it will be

\footnotetext{
-The writer feels that the time has not yet come to present a definite program of instruction for various ages. This must be built up as the result of experimental work by good teachers in the next few years. A very tentative outline is suggested in Chapter. VIII. Notwithstanding this uncertainty as to the best way to get the results we want, and the conviction that we must not make the mistake just now of going too fast in this delicate matter, it has been deemed wise to give some concrete suggestions for particular cases, particularly directed to parents. This appendix is such an effort to deal in the concrete with a few of the things which the parent must meet. In the nature of the case it repeats some of the more theoretical statements in the body of the book, but does so in the effort to adapt the point of view given there to the actual necessities in practice. It will be understood that the appendix is written for the guidance of adults and not for children.
} 
greatly to the parent's advantage to have observed and talked with the child about some of the interesting nature study topics which the garden and field suggest. There are a number of simple books available on nature study. Among these may be mentioned: "Plant and Animal Children" (Torelle); "Transmission of Life" (Naphey); "Life's Story" (Mrs. Hall); "Truths"( Lowry); the reading of which will help the parent to make these talks lay the foundation for more personal answers.

\section{Questions of Early Childhood. \\ Problem I. The Differences between Boys and Girls.} Probably the first question which parents have practical trouble in answering to their own satisfaction relates to the differences, and the reasons for the differences, between the brothers and sisters of the family. When the question is first raised it will not be necessary to go to the foundations of these differences. At first it will probably be sufficient to make it clear that males and females are different in all higher animals: Of course it is no real explanation of a particular case to put it as a general one; but it is a temporary resting-place for the human mind if it can realize the general character of a particular truth. For example, suppose a small boy or girl in the family has for the first time become really observant and conscious of the external physical differences between the sexes. The poignancy of this discovery can be made much less by calling attention to the fact that one is called "brother," "boy," "he," and the other "sister," "girl," "she," and that all men and boys are different from women and girls. They dress differently, they do different parts of the family work, and the like. There is thus a gain in bringing all the common differences into view at once. This includes 
and swamps, so to speak, the special differences without obscuring or ignoring them. At this stage the problem is not that of imparting to the child the whole mass of information in an exact way, but rather of making him feel that it is a well-known matter about which he may talk freely to his mother, and that she will tell him all that he wants to know as fast as he can understand it.

This process of early education will be easier and less attended by abnormal curiosity and embarrassment if there is a good deal of openness and freedom in the early years when children of both sexes in a family are of nearly the same age. Artificial secrecy and too early separation of the children in the nursery and bath makes the problem of satisfying curiosity much more difficult, than if free natural companionship were allowed. Furthermore, the particular form of modesty that it strives for is often apparent rather than real.

Problem 2. The Origin of the Baby. - One of the earliest questions to come into the child mind is of the origin of the new baby in the home. The feverish haste with which impossible explanations are devised is at once a proof of the persistence of the question and our perverted ingenuity in evading it. Possibly something of the same wonder has arisen in the child's mind in its efforts to account for its own origin; but this curiosity is sure to become acute in the child of from 4 to 6 years of age, if a baby is born in the circle of its acquaintance. As has been said before, when the parent is satisfied that the question is clearly present in the child's mind it should be met even if the child should hesitate to ask the question without encouragement. Some children are more diffident than others about asking questions. 
Two special things should be aimed at in answering this question: first, to give the information in such a way as to prevent a morbid dwelling on the subject; and, secondly, to make this information give the child a conception of motherhood. The first task may best be done by the mother herself; and the second by the father, if he is the right sort of man.

It is important, however, for parents to realize that these two phases of the subject should be so handled as to secure more than a formal, satisfying answer to the young child's questionings. By means of this information the parent must try to give the child the beginnings of a fine and reverent outlook on life and the nature of the home. It should take the form of the most intimate confidences. If it were merely information, the child would sooner or later stumble upon it in some way. We are seeking to use information to develop wholesome attitudes and respect for life.

If the child lives in the country, and knows something of chickens and birds and the eggs that they produce, and perhaps also, something of young mammals, such as pigs and calves and colts, it is quite possible to lead him to understand the steps in reproduction by showing him first the eggs in the body of a hen dressed for table, and then eggs after they are laid such as he has been in the habit of seeing and from which, as he knows, young chickens are hatched. He may be told that all animals come from such eggs; and all eggs are formed in the body of the mother. From this he may be led to understand that, in the case of hogs and cows and dogs, the eggs remain in the body of the mother and grow and "hatch" there, instead of hatching in a nest outside, as in birds. It can 
be shown that the little mammal is much safer within the body of its mother, and that it finally comes to the outside world in somewhat the same way as the large eggs of the birds,- but through a separate opening,- the vagina. The position of this organ can be shown the child in these animals without any occasion for embarrassment whatever, at this early stage. See Figs. 9 and ro. It can then be explained that the human mother produces just such eggs and carries the little child in her body in just the same way until it is strong enough to live outside and breathe and take its nourishment as the other mammals do. The véry fact that this is true of so many other animals will help to make the knowledge seem less personal.

After this information is given to the child by the mother, the father should refer to the difficult and dangerous task which the mother performs in carrying and supporting the baby; should indicate how much discomfort and weariness and even sickness it often involves; should refer to the terrible pains and danger to the mother's life that accompany birth; and should show how all this prepares her to love and care for her baby. The father and child, whether boy or girl, can on the strength of this private understanding enter upon a conspiracy of thoughtfulness for the mother which may mean the most beautiful things in the character of the child and with no trace of morbidness or grossness.

Problem 3. The Father's Part in Reproduction. - A third question, the dread of which often makes parents hesitate to answer the earlier ones, relates to the part the father plays in the reproductive process." Ordinarily, this question will occur to the child some years later than the first two mentioned. There is danger, however, that older 
children in advance may seek to impart the information, and if this is done, the knowledge often comes with an exaggerated emphasis, and in such a way as to stimulate a morbid interest and to encourage secrecy rather than the frankness we are seeking. By withholding instruction on this point, parents thus lose the opportunity to keep pure the idea of the father's part by connecting. it with the finer facts of family structure and life, and lose, also, the chance to bind the child to them in the bonds of this common family knowledge. We have here again a much bigger task than the giving of information. It is, indeed, that of using a delicate piece of information to cement the family bonds, and of making the facts of sex contribute to the child's admiration and respect for human life and its relations and thus spiritualizing them, rather than allowing the whole phenomenon to become a mere by-word and subject for suggestive and vulgar reference.

In practice it is again much easier to give this information to the country child, in an incidental way, than to the child unacquainted with animal life. It is quite possible however, anywhere, to show the child, by a series of gradual steps, the parts played by the male and female in reproduction, and to do this in such a way that the mind will come to the main facts in human life without shock. *For example, any flower of which the child is fond may be taken. The lily is a good illustration, because it is a large flower and its parts are conspicuous. While what we see in the lily is not, in a strict scientific sense, exactly parallel to fertilization in animals, it is sufficiently so for our present purpose. Deep within the tissues of

\footnotetext{
- There are now available to parents numerous booklets dealing with this phase of the subject and couched in simple terms. One such is "Plant and Animal Children" by Ellen Torelle, publisbed by D. C. Heath \& Co.
} 
the flower occurs a process exactly similar to that which we seek to explain.

The accompanying diagrams (Figs. I I and I2) will help the reader to follow the process. The pistil $(p)$ in which the seeds, or young plants, develop contains the mother organs. The pollen, or powdery material produced by the stamens ( $s$, supplies the fatherelements. It can be shown that the seeds will not be developed if the male, or fatherelement is not added. This is known as fertilization. This process of fertilization is necessary also in all the animals the child knows. The

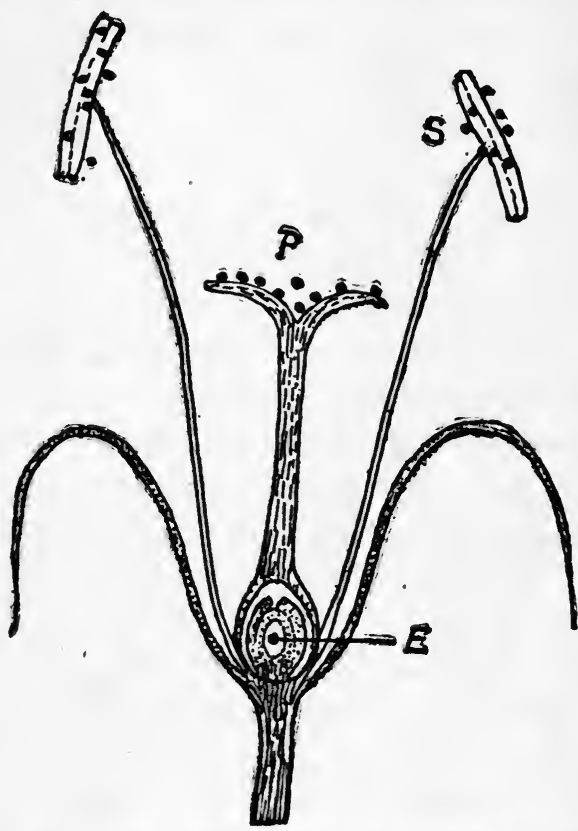

Fig. Ir. The flower of the lily. $E$ is the egg, which is developed in a cavity inside the pistil $(P) ; S$ is the stamen which produces the powdery pollen. This falls on the pistil $(P)$ and produces a male cell that fertilizes $E$. (See next figure.)

character of the process may be followed in Fig. I2. See also Fig. 7 .

The mother-fish swims along and lays numerous small eggs in little hollows in the sand, or in similar places. The father-fish then swims over the eggs, and pours out from his body other bodies much smaller than the eggs, 
and similar to those produced by the pollen in the lily. These must unite with the eggs in order to make them

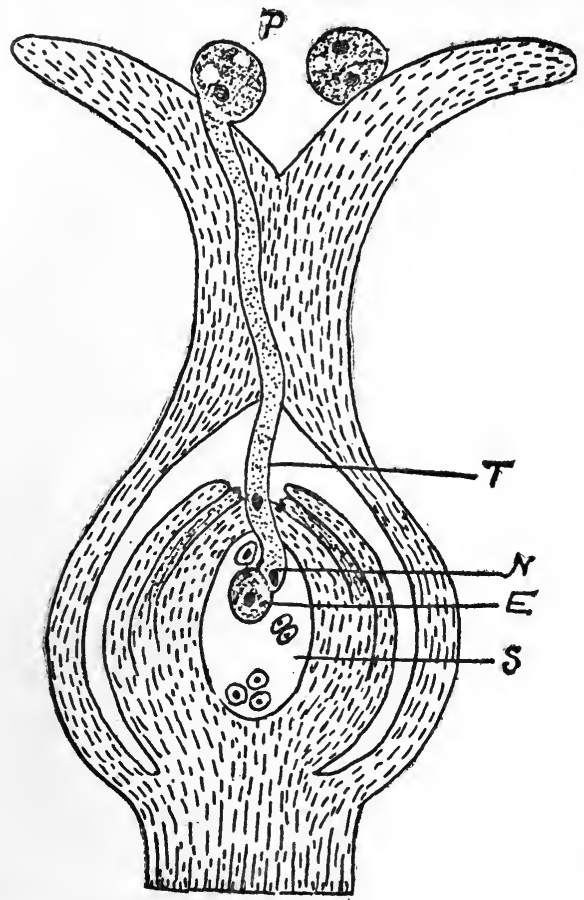

Fig. 12. Fertilization in the lily (much enlarged). $E$, the egg cell, to be fertilized, lying in the embryo sac $(S)$ : $P$, the pollen, which has fallen on the top of the pistil, sending down a tube $(T)$. This tube penetrates the tissues and finally grows into contact with the egg or female cell. In the tube occur one or more male (sperm) nuclei $(N)$ one of which enters the egg and fertilizes it. In this way a new embryo starts, made up of a male and a female reproductive body (gamete). This is essentially what takes place in all the higher animals and plants, including man.

develop into little fish.

In chickens, these cells of the father must be placed in the body of the mother because they must unite with the young egg before the hard shell is formed about it. Because of this shell, chickens cannot behave like fish in fertilizing the egg.

For still another reason, the same is true of mammals, as horses and cats and hogs and "humans." The young in these animals, as we have seen, are kept in the mother's body, and therefore the eggs must be fertilized within just as in the birds, although they have not a shell.

In the country the child is quite sure at an early age to see copulation among animals. This is the act whereby 
the sperm or male cells are brought into the region of the egg-cells so that fertilization may take place. It is in connection with this act that all the wonderful and powerful instincts and impulses of sex are developed. This act of copulating is sure to interest and excite the curiosity of the child whenever he sees it. It should not make the act any more objectionable or dangerous to the mind of the child if he is made to understand that this is the process whereby all new lives are begun. Indeed it is much more wholesome so than that he should come to see in it a vulgar incident to be thought of as a secret, suggestive, and indelicate jest. Possibly it is well to emphasize three things in connection with all this: (I) The scientific and not the vulgar names should be given to all these -processes and the organs involved; (2) The family and private nature of the information should be stressed in such a way as to make the child feel that these matters are just as pure and open as any other, within the family, but are not any more suitable for public discussion than are other family affairs; (3) The wrongness of fatherhood or motherhood among humans without marriage may very properly crown this teaching.

\section{Special Problems of Adolescent Boys.}

Problem I. Masturbation Among Boys. - As boys begin to feel the promptings of sex and to experience its desires and the erections of the organs of copulation, the parent is confronted by a somewhat critical problem. How can we bring proper cautions to the boys about masturbation, before they have begun to indulge in it, in such a way as to do them more help than harm? Are we not in danger of introducing them to the act of self- 
abuse rather than of helping them avoid it? Doubtless, with some boys, there is a real danger here; but the warning may be given by the right man and in the right way, so as to provide real and convincing reasons that will fortify most boys against this vice. This, however, cannot be done if we think of masturbation as the chief thing to be considered, or allow the child to do so. Masturbation is merely a special case, - and a small abnormal one,- - under a much more extensive and important head. What we need to do is to show the boy that his desires, the erection of his organs, and the other changes in his body and mind are merely natural steps by which his developing sexfunctions give him the qualities of body and mind and temperament that belong to normal and well-developed men. It is of the greatest possible aid to us at this stage that there is nothing that the pre-pubertal boy wants to be so much as a vigorous manly man.

Masturbation should be treated primarily in its bearings on these ambitions, and in a way quite incidental to the general facts of manly development. In order to do this well, we must be able to give a real, workable reason,- a reason that will appeal to the boy over and above any conviction that masturbation is in itself disgusting and wrong. Something like the following will bring the matter to his knowledge and the state of his aspirations:- It is well established that the destruction of the testes, or male sex-glands, in early life changes very profoundly the male animal. The rooster or cat whose testes have been removed in early life will grow fat and soft instead of strong and vigorous; and will tend to be lazy and cowardly instead of having the normal characteristics of its kind. Much the same thing happens in men. Eunuchs, made 
so early in life, are not strong, brave, open, virile men, such as every real boy wants to be, with a man's voice and appearance and powers; but are fat, sleek, soft, cunning, often lazy, beardless, - effeminate beings whose voices have never changed to the man's range. This is not an accident. It is in all cases because the testes have not been allowed to pour into the blood their products, the work of which is to bring about the development of these big qualities that all men want to have.

It is possible for boys to handle and massage their organs in such a way as to cause the lloss of the fluids that enable them to develop muscle, and other masculine qualities. Thus they are in danger of preventing the full development that they most want. Besides all this, masturbation tends to make the organs and the nerve centers that control them sensitive and irritable; and in this way the bodily and mental development is liable to become actually unnatural and morbid.

A boy should be made to feel that there is something unnatural and abnormal about any companion who approaches him urging him to this act; and it is quite possible so to fortify him in advance, through his conception of normal manly behavior and ambitions, that he will feel only disgust at any such approach.

In addition to these items of instruction there are certain precautions which will greatly aid parents in this task. Absolute cleanliness of the parts and prompt care for the calls of nature should early become habitual. Boys should be constantly busy with work, with active games, and with wholesome reading. They should go to bed early and always physically weary, so that they will go to sleep at once. If possible each boy should have a separate bed, 
and should not be allowed to lie in bed after he wakes in the morning. These habits are valuable in other ways than in preventing sex-perversions; but they would be worth while if this were their sole contribution.

Problem 2. Seminal Emissions. - All that is necessary here is to show the boy that this is only nature's way of getting rid of any excess, and that such occasional escape of seminal fluid during sleep is normal and natural. The need of reference to it lies in two facts. In the first place, lack of this knowledge may bring uneasiness to the inexperienced boy, and may drive him into the hands of advertising quacks who first frighten, and then profit by the fright of maturing boys. In the second place, masturbation and voluptuous thought and talk tend, by making the nerve centers over-sensitive, to make emissions so frequent as to be a drain on the system, and to check the proper manly development. When there is any ground to believe that this is the case with any boy, a reliable physician should at once be consulted.

Problem 3. Early Love and Chivalry. - Parents, and older brothers and sisters find much place for fun in the early admirations of the boy for the other sex. These early emotions however, - whether the fondness of a mere child for some mature woman, as is often the case, or the attraction of the boy to girls of his own age,- may be used, and ought to be used, by the parent to stimulate and develop gradually good standards of courtesy and chivalrous respect for women as such. Instead of ridicule, teasing and deprecatory remarks about the object of enthusiasm, and the assurance that it is a short-lived emotion, this is nature's opportunity to bring a very fine boyish impulse to the strength that will serve good purposes 


\section{APPENDIX}

later. Something of the devotion he has come to have for his mother and his sweetheart may at this time be extended to all women. Furthermore, there is no motive which will so greatly help to keep the boy clean and loyal to a single standard of sex morals as these sentiments for a girl in whom he has confidence. Parents are much in error in their practice at this point.

\section{The Special Problems of the Adolescent Girl.} There is no reason why these problems should present great difficulty to intelligent parents. The kind of confidence which would make it easy for the mother to instruct her daughter effectively certainly ought to be the normal thing. It is, however, very apparent that a large percentage of mothers do not render this necessary service to their daughters. The problems confronting the mothers at this point are chiefly three:- matters of normal bodily development at this period, and their meaning; matters of health; and the mental attitude necessary for girls to assume.

Problem I. Matters of Bodily Development. - Some time before the coming on of the normal changes of puberty, the mother ought to make clear to the daughter the nature of the external changes that are to come, so as to avoid the uncertainty and possible shock that may ensue if they come entirely unannounced. The facts are simple enough: -rapid growth and the possible awkwardness and ungainliness of the pre-pubertal and early pubertal age, the development of a womanly form in the enlargement of the neck, bust and hips, the appearance of hair in the armpits and pubes, and the beginning of menstruation. There is a value to the child in merely knowing these facts and 
in being prepared for them; but the great educational value comes from appreciation of their meaning. It is the privilege of the mother in giving this information to make more real the meaning of motherhood, and to show that all these developments are in preparation for this possibility. Menstruation and all the other changes are symptoms that eggs are ripening, and that the child is becoming a woman. Just as in the case of the boy, the ideal of sound and normal development should be kept to the front and be made to seem desirable; the relation of such development to personal appearance and to happiness should be made dear; and the conditions under which this soundness may be had should be emphasized.

Problem 2. The Problem of Health.-Apart from the idea of allowing the normal unfolding of the natural powers and functions, there are some particular matters about which a mother should inform herself in order that she may make them very emphatic and clear to the daughter. These items are treated at some length in the body of the book (Chapter VI, Section 8), and it will be necessary here to refer only to two or three points. The illhealth and distress which may come to the young girl through sex, arise chiefly in connection with two things: (I) loss of blood through menstruation, and (2) the falling of the uterus. In both connections, such diet, exercise and promptness in obeying the calls of nature as will prevent constipation are most important.

In respect to the menses the mother should of course teach and insist on the formation of habits of the utmost cleanliness. The proper regimen of the young girl involves a knowledge of the fact that menstruation means a drain on all the vital resources, and leaves the system weak, de- 
pressed, and open to shock and disease; that the uterus and other sex-organs are at this period highly congested with blood; and that, in consequence, exposure to extremes of any kind, and the undertaking of tasks that overtax the strength are sure to bring evil results.

In treating this situation mothers are in danger of falling into one of two errors: - either that of neglecting to give any attention to the condition and trusting to nature to care for it; or of coddling the child and, by a program of over-protection, diminishing the natural ability of the system to recuperate and restore, and at the same time creating an unnecessary and abnormal consciousness of the condition. What should be aimed at is a thorough understanding of the dangers of exposure and over-activity, a knowledge that extra care must be taken at this time and immediately afterwards and a willingness to take such means as will build up the strength to a maximum between periods. The application of plain common sense is demanded here, as elsewhere, for health.

In respect to displacement of the uterus or womb, the first purpose should be to prevent it. This means that the pre-pubertal girl should be encouraged to take all the outdoor and indoor exercises calculated to build up the general system and to strengthen the muscles of the abdomen and the back. As the age of puberty comes on, special exercises for the back and abdomen should be taken. Such an exercise as lying full length on the back, and raising the legs first alternately, and then both together to a vertical position is excellent for the purpose. At least once a day the adolescent girl should take the "knee and chest" position for five minutes, simply as a gymnastic exercise. This is done by kneeling on the floor, then 
bringing the chest and face fully to the floor, placing the arms out sideways from the body. This tends to restore the womb to its natural position, and is a good exercise just before retiring. Whenever there is reason to believe, because of painful menses or of dragging sensations in the pelvic region, that the uterus is displaced, the family physician should make an examination and prescribe treatment.

Problem 3. The Problem of Right Mental Attitudes.This is too large a question to treat at length here; but even in the earliest days of a girl's life the mother should find a way so to inculcate those attitudes of self-respect and regard for womanly purity, of reserve and modesty, of dignity, of appreciation of the rôle of wife and mother, that these things will consciously or unconsciously influence every later act.

Because of the less strenuous character of female impulses the task of the girl is not so much one of self-restraint as in the case of the boy. Her duty is rather that of conserving and guarding the interests of the race, as well as her own standards and ideals. Her training will be best when we as parents and teachers come to recognize this as her specific function, and bring to bear every possible stimulus to develop her understanding of all it implies. The loss of reserve on the part of girls and women is always the most dangerous door to sex immorality.

In all that has been said in the preceding chapters, the meaning of the writer is this:- If parents and teachers can arrive at the point at which they can use sympathetically all the best, which they as teachers know, to coöperate with nature in the upbuilding of their children, they may 
greatly increase the number of those who may be regarded as successful in converting sound knowledge into right sex-conduct. Nature's task is the making of sound men and women able to reproduce their kind. She has an ordered and effective way of accomplishing this from infancy to maturity. Each of her steps adds something vital and worth while to the product. It is to the interest of all that we should understand each of these natural steps and its contribution. We need to know this, both that we may allow it to make its positive contribution, and at the same time not permit it to linger on in abnormal strength, inhibiting the next step. The proper development of the sex-function, impulses, and their corollaries is the first biological necessity: to develop through them the mental, social, and moral control of them is to-day one of the prime human necessities. 




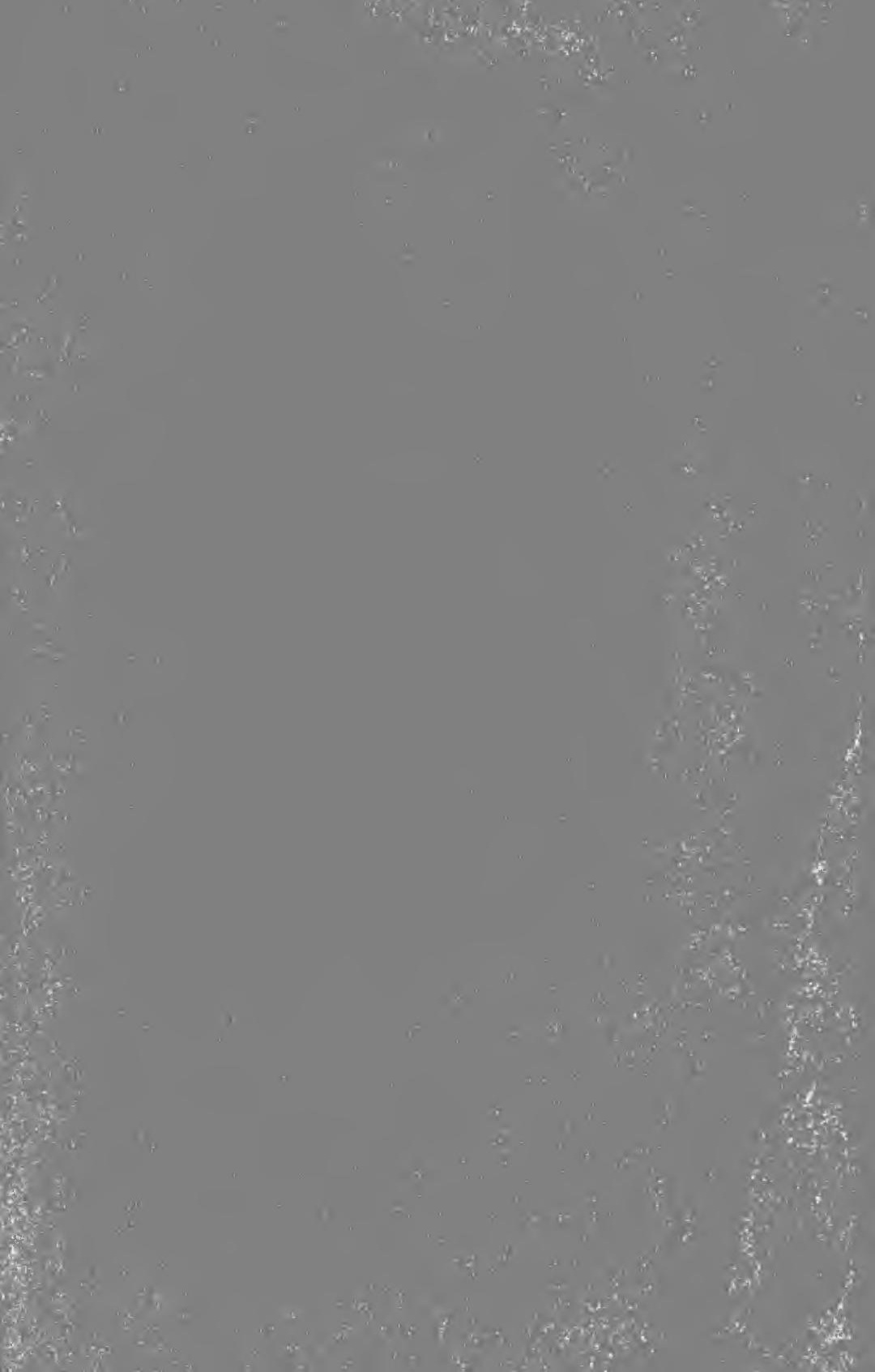




\section{DAY USE}

RETURN TO DESK FROM WHICH BORROWED

\section{LOAN DEPT.}

This book is due on the last date stamped below, or on the date to which renewed.

Renewed books are subject to immediate recall.

\section{De 58 BB NHA}

REC'D LD

NOV 251958 \% 66 9809

2. MAR'59DF

RECD LD
MAR 251959

SEP $1161 \mathrm{~S}$

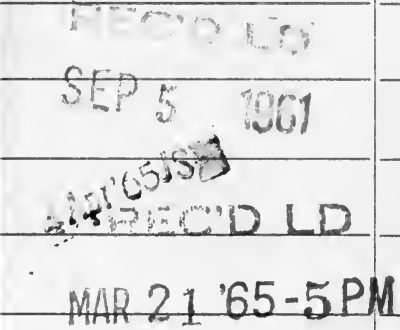




$$
\begin{array}{r}
482349 \\
H Q 56 \\
\text { G2 }
\end{array}
$$

THE UNIVERSITY OF CALIFORNIA LIBRARY 
(2)

and (16) 